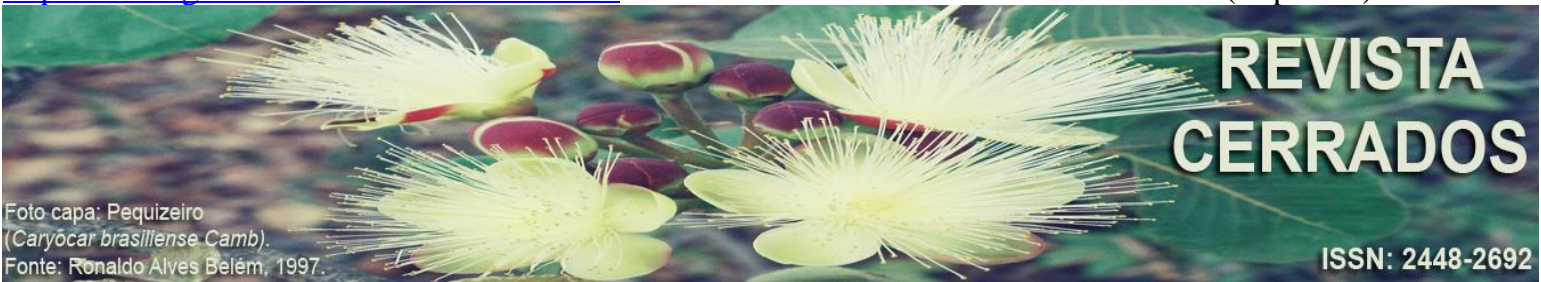

\title{
CONFLITOS TERRITORIAIS NA AMAZÔNIA ORIENTAL, OESTE DO ESTADO DO PARÁ: duas situações distintas, mas a mesma lógica imperativa
}

\section{TERRITORIAL CONFLICTS IN THE EASTERN AMAZON, WEST OF PARÁ STATE: two distinct situations, but the same imperative logic}

\section{CONFLICTOS TERRITORIALES EN LA AMAZONIA ORIENTAL, ESTADO OESTE DE PARÁ: dos situaciones diferentes, pero la misma lógica imperativa}

\author{
Jondison Cardoso Rodrigues \\ Universidade Federal do Pará - UFPA, Belém, Pará, Brasil \\ E-mail: <jondisoncardosorodrigues@gmail.com>.
}

\section{RESUMO}

Há hoje na Amazônia novos agentes (estados-nações, multinacionais, bancos e fundos), novos interesses e novas escalas de espoliação e integração financeira, cujos resultados práticos, materializados nos territórios, são de uma padronização de violências e conflitos, por exemplo: intimidações, agressões físicas e verbais, ameaças de morte, tentativas de assassinatos e mesmo assassinatos. Todavia, existe a emergência de particularidades e singularidades, em termos de violências e formas dinâmicas de conflitos na Amazônia Oriental. Tais particularidades e singularidades são "visualizadas" no Oeste do estado Pará, onde mais recentemente se constitui palco (de uma cartografia) de intensificações de conflitos, face principalmente à territorialização do agronegócio (empresas de fertilizantes, armazéns, portos, postos de combustíveis, multinacionais). Considerando tal discussão, o objetivo aqui é descrever e analisar os Conflitos Territoriais (CTs) produzidos junto: 1) à comunidade tradicional em Rurópolis (Comunidade de Santarenzinho); e, 2) à comunidade de pescadores em Itaituba (Colônia de pescadores Z-56), frente à territorialização do agronegócio. A questão a perseguir é: Quais são os atores envolvidos e as formas (singularidades e padrões) de tais CTs assim como os territórios em disputa, "visões de território", nesses CTs da Amazônia Oriental, oeste do estado do Pará, especificamente a comunidade Santarenzinho e dos pescadores artesanais de Itaituba?

Palavras-chave: Conflitos territoriais. Comunidade. Lutas e disputas territoriais. Amazônia 
RODRIGUES, J. C.

Conflitos territoriais na Amazônia oriental, oeste do estado do Pará: duas situações distintas, mas a mesma lógica imperativa

\begin{abstract}
There are new agents in the Amazon now (nation-states, multinationals, banks and funds), new interests and new scales of spoliation and financial integration, whose practical results materialized in the territories are of a pattern of violence and conflicts, for example: intimidation, physical and verbal assaults, death threats, assassination attempts and murders. However, there is an emergence of particularities and singularities, in terms of violence and dynamic forms of conflict in the Eastern Amazon. Such particularities and singularities are "visualized" in the west of the Pará state, of which, more recently, it constitutes the stage (of a cartography) of intensification of conflicts, mainly due to the territorialization of agribusiness (fertilizer companies, warehouses, ports, gas stations, multinationals). Considering such discussion, the goal is to describe and analyze the territorial conflicts (TCs) produced with: 1) the traditional community in Rurópolis (Santarenzinho Community); and, 2) the fishing community in Itaituba (Colony of fishermen Z-56) in view of the territorialization of agribusiness. Having as a question to pursue: What are the actors involved and the forms (singularities and patterns) of such TCs as well as the disputed territories and "territory views" in these TCs in the Eastern Amazon, west of the state of Pará, specifically the Santarenzinho community and the artisanal fishermen from Itaituba?
\end{abstract}

Keywords: Territorial conflicts. Community. Territorial fights and disputes. Amazon.

\title{
RESUMEN
}

Hoy en la Amazonía hay nuevos agentes (naciones-estados, multinacionales, bancos y fondos), nuevos intereses y nuevas escalas de expoliación e integración financiera, resultados prácticos materializados en los territorios es un patrón de violencia y conflictos, por ejemplo: intimidación, agresión física y verbal, corrigiendo muerte, asesinatos y asesinatos. Sin embargo, surgimiento de particularidades y singularidades, en términos de violencia y formas dinámicas de conflicto en la Amazonía Oriental. Tales particularidades y singularidades se "visualizan" en el occidente del estado de Pará, del cual somos escenario (de una cartografía) de intensificación de los conflictos, principalmente por la territorialización de la agroindustria (empresas de fertilizantes, depósitos, puertos, estaciones de plan, multinacionales). Discusión el objetivo es describir y analizar los conflictos territoriales (CTs) obtenidos de: 1) la comunidad tradicional de Rurópolis (Comunidad Santarenzinho); y, 2) la comunidad pesquera de Itaituba (Colonia de pescadores Z-56) enfrenta una territorialización de la agroindustria. Teniendo como pregunta a seguir: ¿Cuáles son los actores involucrados y las formas (singularidades y patrones) de tales CTs así como los territorios en disputa y "visiones de territorio" en las CTs en la Amazonía Oriental, al oeste del estado de Pará, específicamente la Santarenzinho y pescadores artesanales de Itaituba?

Palabras-clave: Conflictos territoriales. Comunidades Luchas territoriales y disputas. Amazonas. 
RODRIGUES, J. C

Conflitos territoriais na Amazônia oriental, oeste do estado do Pará: duas situações distintas, mas a mesma lógica imperativa

\section{INTRODUÇÃO}

O Oeste do estado Pará é uma sub-região composta por vinte municípios: Altamira, Anapu, Aveiro, Belterra, Brasil Novo, Itaituba, Jacareacanga, Medicilândia, Mojuí dos Campos, Novo Progresso, Novo Repartimento, Pacajá, Placas, Porto de Moz, Rurópolis, Santarém, Senador José Porfírio, Trairão, Uruará e Vitória do Xingu. Em termos de extensão físico-territorial, possui significava dimensão, representando $33,46 \%\left(417.628 \mathrm{~km}^{2}\right)$ do território do estado do Pará $\left(1.248 .000 \mathrm{~km}^{2}\right)$. Além de possuir: i) uma das maiores concentrações de sociobiodiversidade; ii) um dos maiores aquíferos (Aquífero Alter do Chão); iii) a maior concentração espacial (e tamanho) de bacias hidrográficas do Brasil: Xingu, Tapajós e Baixo Amazonas; iv) grandes geozonas minerais (aurífera, bauxitífera, calcarica, fosfaltica); e, v) grandes extensões de terras - além de "baratas" e agricultáveis.

Essa sub-região é um "microespaço" representativo de uma cartografia histórica de conflitos, fruto de um processo histórico, de formação socioeconômica e política (CASTRO; CAMPOS, 2015), que se construiu socialmente, por meio da (uso da) violência: física, simbólica, epistêmica, étnica e de gênero (colonialidade racista!!! ${ }^{1}$ ). Portanto, essas violências se constituíram como resultado, meio e condição para reprodução e ampliação do controle simbólico, político, mas, principalmente, dos ganhos econômicos exorbitantes de frações hegemônicas: elites locais, regionais e nacionais, empreiteiras, mineradoras, multinacionais e bancos, ainda mais recentemente, fundos.

Muitos dos conflitos recentes estão ainda ligados à macropolíticas desenvolvimentistas para região e a lógica colonialista-mercadológica (neo)extrativista (CASTRO, 2017a; BRITO; CASTRO, 2018; LOUREIRO, 2019), de exploração, espoliação de territórios, territorialidades de vida e de reprodução (existência) social. Muitas vezes expressos na questão fundiária (BENATTI et al, 2008; CASTRO, 2008; TORRES, 2012; CPT, 2020).

Segundo Castro (2017b), a Amazônia paraense:

\footnotetext{
1 Segundo Loureiro (2019, p. 210): “O sequestro da autonomia política da região, seguido do seu disciplinamento pelo bloqueio das ações regionais e locais, exigia uma alteração no quadro cultural, com a diminuição das populações tradicionais, populações interioranas próprias da região e, especialmente, índios. Tais grupos sociais eram concebidos e o são ainda hoje por parte da tecnoburocracia e pelos grupos econômicos, como povos atrasados, primitivos, portadores de uma cultura inferior, que criam obstáculos ao desenvolvimento e que só teriam a ganhar integrando-se à sociedade urbana e "civilizada", devendo por isto desocupar suas terras para destiná-las a atividades ditas "modernas"”.
}

Revista Cerrados, Montes Claros/MG, v. 18, n. 02, p. 474-511, jul./dez.-2020. 
RODRIGUES, J. C.

Conflitos territoriais na Amazônia oriental, oeste do estado do Pará: duas situações distintas, mas a mesma lógica imperativa

[...] está associado a uma história de violência colonial - coronelista e patrimonialista - relacionada ao território e às tensões sobre populações ali residentes, sobretudo no que diz respeito aos processos de colonização e abertura de grandes eixos rodoviários, desde a rodovia Belém-Brasília, nos anos 1960. Conflitos agrários, expropriação de populações tradicionais de suas terras, genocídio indígena, grilagem de terras, chacinas e mortes anunciadas por mandantes e seus pistoleiros, marcam as imagens e tornam a violência uma chave de interpretação da sociedade (CASTRO, 2017b, p. 9).

Essa história de violência colonial dá-se, ainda segundo Castro (2017b), devido a um mercado hiperglobalizado, cujos interesses econômicos nos recursos naturais amazônicos ampliaram-se assim como as pressões, violências, tensões, disputas e conflitos sobre as florestas, as águas, a terra, solo e o subsolo. Seria uma espécie de movimento duplo: expansão de frentes, exploração econômica (madeira, garimpo, agricultura mecanizada e soja), tensões e conflitos territoriais. Tendo como elemento incentivador (apoio) o Estado brasileiro, em termos de políticas, planos e programas.

Essa atuação, no caso desse controle político do Estado brasileiro, é retomado face à globalização e geopolítica mundial de participação "forte" dos Estado-nações (RODRIGUES, 2018). Esse formato de participação do Estado é visualizado no Brasil, sobretudo, na década de 2000, por meio de políticas e planejamentos de matriz neodesenvolvimentistas, neoextrativistas, com fortes investimentos em infraestrutura (hidrelétricas, rodovias, infovias, aeroportos e portos) para à exportação de commodities (RODRIGUES, 2018; RODRIGUES; LIMA, 2020), acompanhado do incentivo à produção de mercados de ações, terras, infraestruturas e serviços (neoliberalismo financeirizado).

Tais ações (geo)políticas do Estado brasileiro integram-se ao processo de mundialização e financeirização global, como forma de cumprir uma agenda de "consenso de commodities" (SAMPA, 2015), pautada na divisão internacional do trabalho: 1) com lugares que serão exportadores de produtos in natura, semielaborados e matérias primas; e, 2) lugares que serão exportadores de máquinas, equipamentos, patentes, grandes tecnologias e investimentos. Agenda essa que se pauta na massiva implementação de megaprojetos neoextrativistas, produção de narrativas legitimatórias, de positividade e imprescindibilidade de megaprojetos. Portanto, configurando a continuidade da dimensão compreensiva e associativa da Amazônia enquanto "almoxarifado do Brasil" (LOUREIRO, 2019, p. 207), ou, mais especificamente "almoxarifado do mundo". 
RODRIGUES, J. C.

Conflitos territoriais na Amazônia oriental, oeste do estado do Pará: duas situações distintas, mas a mesma lógica imperativa

Megaprojetos neoextrativistas esses que constitui cada vez mais estruturas estampadas na paisagem, nas dinâmicas e políticas territoriais no e para o Oeste do estado do Pará, com investimentos estrangeiros e especulativos, ligados, sobretudo, ao agronegócio, na construção de uma logística intermodal, particularmente, de complexos portuários. Já há seis portos operando, em Itaituba, dos seguintes grupos econômicos: Unitapajós, Cianport, Hidrovias do Brasil, Cargill, Transportes Bertolini/ADM e Caramuru Alimentos (RODRIGUES; RODRIGUES; LIMA, 2019); e, há o planejamento de construção de mais de quarenta portos na região Oeste do estado Pará, envolvendo o município de Itaituba e Rurópolis.

Além disso, há outros projetos que se costuram com projetos portuários como forma de promover a fluidez das commodities agrícolas, isto é, contribuir na sustentação logística dessa fluidez e no monopólio territorial para soldar a cadeia produtiva e especulativa de commodities, no caso: ferrovias (Ferrogrão e Ferrovia Paraense), hidrovias (Teles-Pires e Tapajós), concessão da rodovia à Br-163, pequenas centrais hidrelétricas (do Cupari e Itapacurá/Rurópolis e Itaituba) e hidrelétrico (complexo hidrelétrico São Luiz do Tapajós, em: Cachoeira do Caí, Jamanxim, Cachoeira dos Patos, Chacorão, Jardim de Ouro, Jatobá e São Luiz do Tapajós). Além da hidrelétrica em Oriximiná, no Oeste do estado do Pará (RODRIGUES; LIMA, 2020).

Considerando tal discussão e contextualização sobre o terreno que se pavimenta na Amazônia, particularmente no Oeste do estado Pará, e as intensificações de conflitos, face principalmente a territorialização do agronegócio, o objetivo deste artigo é descrever e analisar os Conflitos Territoriais (CTs) produzidos junto à uma comunidade tradicional em Rurópolis (Comunidade de Santarenzinho) e também junto a pescadores(as) artesanais de Itaituba (Colônia de pescadores Z-56), face à territorialização do agronegócio. A partir de tal objetivo temos a seguinte questão a perseguir: Quais são os atores envolvidos e as formas (singularidades e padrões) de tais CTs, assim como os territórios em disputa e "visões de território" nesses CTs na Amazônia Oriental, Oeste do estado do Pará, no caso a comunidade Santarenzinho e dos(as) pescadores(as) artesanais de Itaituba?

A relevância do artigo encontra-se em “(ex)por” em cena pública novos padrões de relação territorial (relação de poder) no campo e na cidade, correlacionando os conflitos com os setores de exportação de commodities e uso de recursos (SHEIDEL et al, 2020), isto é, 
RODRIGUES, J. C.

Conflitos territoriais na Amazônia oriental, oeste do estado do Pará: duas situações distintas, mas a mesma lógica imperativa

as contradições e territorializações espoliativas ligadas ao setor do agronegócio. Além disso, evidenciar a política neodesenvolvimentista do Estado brasileiro, que vem contribuindo significativamente para a supressão de territorialidades de existência, reprodução social e a "diversidade de formas de existência coletiva de diferentes povos e grupos sociais em suas relações com os recursos da natureza" (ALMEIDA, 2004, p. 9).

A abordagem metodológica interdisciplinar (e qualitativa) adotada aqui nesse artigo deve-se ao fato de que os fenômenos sociais e ambientais na e da Amazônia são um mosaico complexo de: paisagens, populações, culturas, identidades, crenças, rituais, religiosidades, espiritualidades, tradições, cosmovisões, territorialidades, temporalidades, dinâmicas territoriais recentes e históricas de agentes políticos e econômicos com interesses distintos, assim como conflitos e desigualdades sociais sub-regionais e microregionais. Segundo Minayo (2010), a compreensão interdisciplinar se calca na apreensão e análise da totalidade, por meio da inter-relação entre disciplinas, múltiplos olhares e o entrecruzamento de saberes como estratégia para compreensão, interpretação e explicação de temas complexos.

Do ponto de vista da operacionalização do processo de pesquisa, o caminho aqui traçado deu-se com a definição e o critério de escolha do recorte temporal e espacial da pesquisa. O recorte temporal foi de 2014 a $2019^{2}$, cujo critério de escolha temporal está relacionado ao período de desenvolvimento da nossa tese de doutorado (entre 2014 e 2018) e pós-doutorado (em 2019), particularmente convergindo com a territorialização do agronegócio. Agronegócio esse ligado a complexos portuários (Unitapajós, Cargill, Hidrovias do Brasil, Transportes Bertolini/ADM, Caramuru Alimentos e Cianport). Com relação ao recorte espacial, Oeste do estado do Pará (Rurópolis e Itaituba), foi devido à grande concentração de políticas públicas e projetos econômicos do e para o agronegócio, assim como "locais" que começavam a emergir (e intensificar) "fatos" e casos/eventos de conflitos territoriais.

Durante o período de pesquisa, foram realizadas observações assistemáticas no distrito de Miritituba/Itaituba e no rio Tapajós, onde se localizam os complexos portuários (RODRIGUES; RODRIGUES; LIMA, 2018; RODRIGUES; LIMA, 2020), com registros fotográficos dos portos, do rio tapajós e da comunidade de Santarenzinho. Assim como foram

\footnotetext{
${ }^{2}$ As pesquisas de campo ocorreram em: i) julho de 2014; ii) fevereiro e novembro de 2015; iii) maio, agosto e outubro de 2016; iv) junho e setembro de 2017; v) novembro de 2018; e, vi) maio e dezembro de 2019. Revista Cerrados, Montes Claros/MG, v. 18, n. 02, p. 474-511, jul./dez.-2020.
} 
RODRIGUES, J. C.

Conflitos territoriais na Amazônia oriental, oeste do estado do Pará: duas situações distintas, mas a mesma lógica imperativa

realizadas entrevistas semiestruturadas com o presidente da Associação de Moradores de Santarenzinho e com o Presidente da Colônia Pescadores de Itaituba - com objetivo de capturar as experiências e vivências face ao uso corporativo dos territórios promovidos por agentes econômicos portuários ligados ao agronegócio.

Para Minayo (2012, p. 623):

[...] é preciso saber que a experiência e a vivência de uma pessoa ocorrem no âmbito da história coletiva e são contextualizadas e envolvidas pela cultura do grupo em que ela se insere. Toda compreensão é parcial e inacabada, tanto a do nosso entrevistado, que tem um entendimento contingente e incompleto de sua vida e de seu mundo, como a dos pesquisadores, pois também somos limitados no que compreendemos e interpretamos.

Portanto, o ato de entrevista (semiestruturada) funciona como captura de um movimento, em que o narrado e o vivido por si estão visualizados pela dinâmicas experienciadas e tais traduções de narrativas são formas de apreensão de traços, processos recorrentes (que são sequências recorrentes de situações e ações), evidenciando a singularidade, sua historicidade, sua subjetividade inserida em uma coletividade (BERTAUX, 2020).

Dentro do processo de análise, o aporte teórico-analítico pauta-se na abordagem da ecologia política. Abordagem cuja perspectiva é multiescalar e crítica, na compreensão de ações, políticas e reverberações socioambientais. Segundo Leff (2015, p. 46):

A ecologia política tem suas raízes e estabelece sua identidade disciplinar no poder relações que atravessam todas as estruturas / estratégias teóricas, discursivas e econômicas a apropriação social da natureza (Marx, 1965; Foucault, 1980). Assim, a prática de ecologia política diz respeito principalmente à desconstrução de teorias, descolonialização de modos de pensamento e confronto de estratégias de poder-emconhecimento [...] [Tradução nossa].

Tal compreensão analítica da ecologia política buscaria também descortinar ou revelar processos políticos, econômicos, culturais e ecológicos do passado e do presente, em uma região geográfica relacionados a uma ontologia da diversidade, de políticas (da produção) da diferença, de conflitos de (re)distribuição ecológica, de reapropriação cultural da natureza, dos territórios (LEFF, 2015). No caso, dando enfoque: i) nos atores marginalizados e insivibilizados; ii) nas estruturas, relações e agentes econômicos e políticos e práticas discursivas (poder). 
RODRIGUES, J. C

Conflitos territoriais na Amazônia oriental, oeste do estado do Pará: duas situações distintas, mas a mesma lógica imperativa

Tudo isso como forma de "tornar visíveis": 1) os atores marginalizados e invisibilizados, suas territorialidades e lutas territoriais; 2) as estruturas e agentes hegemônicos por trás de injustiças e violação de direitos humanos, não-humanos e étnicos; 3) nas formas sustentabilidade ambiental, a partir de atores que pensam a natureza/território como "bem comum" (e não utilitarista); e, 4) relações de poderes e hierarquias (classificações sociais), formas espoliativas que compõe o projeto (de modernidade) capitalista colonial.

\section{Conflitos territoriais: uma breve incursão e definição}

O debate e discussão sobre a categoria (e/ou objeto de estudo) "conflito", dentro ambiente de pesquisas e estudos acadêmicos, perfaz-se literalmente por uma zona de conflito. Zona de conflito não pelos diferentes ângulos empíricos, causas, os atores/agentes e suas motivações, assim como nas formas, resultados e seus múltiplos efeitos em diferentes contextos-, mas, sobretudo, pelo sequestro da categoria, a evocação da "paternidade" e/ou a produção da crença da verdade depositada em uma disciplina científica. "Produção de crença" essa, aliás, fincada pelo excessivo modo de pensar, categorizar e classificar científicamente pela lente do "mundo ocidental”, colonial (ÁLVAREZ; COOLSAET, 2020; CASTRO, 2019a).

Tais disputas epistemológicas pela categoria expressa-se nas inumeráveis aparições de "termos", muitas das vezes sem conceituação ou definição: conflitos sociais, conflitos interpessoais, conflitos éticos, conflitos urbanos, conflitos fundiários, conflitos trabalhistas, conflitos ecológicos, conflitos ambientais, conflitos socioambientais, conflitos territoriais, conflitos socioterritoriais, conflitos étnicos e identitários. Todos esses "termos", porém, na maioria das vezes, com uma demarcação no elemento empírico, paisagístico, "comportamental" e/ou a lutas, isto é, como adjetivo: acrescentando uma qualidade, uma característica, uma extensão e/ou uma quantidade.

Há outra configuração que vem reduzindo o conflito a um fato meramente técnico (tecnocrata-empresarial), compondo a área ("receita" ou "manual") denominada mediação de conflitos ou resolução de conflitos. Segundo Zhouri (2015), essa área/abordagem, mediação de conflitos, pauta-se no paradigma de modernização ecológica, isto é, na prevenção técnica 
RODRIGUES, J. C.

Conflitos territoriais na Amazônia oriental, oeste do estado do Pará: duas situações distintas, mas a mesma lógica imperativa

dos chamados impactos ambientais, bem como adoção de medidas de mitigação e compensação pela degradação ambiental.

Para Teixeira, Zhouri e Mota (2020, p. 7):

[...] as medidas de indenização e compensação revelam sua funcionalidade para a viabilização institucional e política dos projetos. Isso porque, uma vez previstas e inseridas como condicionantes no processo de licenciamento, permitem a continuidade das obras mesmo sob expressiva recusa das populações afetadas e a flagrante evidência dos danos sociais e ambientais irreversíveis advindos dos empreendimentos.

O fato é que os conflitos (enquanto um fenômeno social) intensificaram-se com o processo de urbanização planetária, do fenômeno de globalização, do projeto de modernidade/colonialidade (BALLESTRIN, 2017) e de financeirização global, a partir da década de 1970. Tal quadro que se reverberou no hiperconsumo de recursos, em efeitos e distribuição desigual de bônus e ônus de ações políticas econômicas, com maior carga dos danos e riscos ambientais do desenvolvimento às populações de baixa renda, grupos étnicos discriminados, populações marginalizadas e vulneráveis (ACSELRAD, 2010). Tudo isso, aliás, que perpassa pelo debate, lutas pela distribuição injusta de "bens" ambientais, como água limpa e ar, ou acesso a terras férteis, além da distribuição injusta de ônus, como exposição à poluição, riscos e ameaças à saúde, meios de subsistência, identidades sociais e culturais (FERNÁNDEZ- LLAMAZARES et al, 2020).

Tal compreensão de distribuição desigual de acesso a recursos, bônus e efeitos vêm sendo analisados e refletidos em termos acadêmicos e políticos (de forma crítica) pelo pesquisador e economista espanhol, Joan Martinez-Alier, da Universidade Autônoma de Barcelona. Martinez-Alier usa o termo "Conflitos de Distribuição Ecológica” (MARTINEZALIER, 2006) que seria equivalente aos termos utilizados pela ecologia política: conflitos socioambientais e conflitos ambientais, como também conflitos territoriais - que, aliás, equiparam-se.

Segundo Martinez-Alier e Roy (2019), o termo Conflitos de Distribuição Ecológica foi cunhado em 1996 pelos economistas ecológicos Joan Martinez-Alier e Martin O’Connor (MARTINEZ-ALER; O’CONNOR, 1996), para descrever conflitos sociais nascidos do acesso injusto aos recursos naturais e encargos injustos da poluição. A causa final de tais conflitos é o crescimento e as mudanças no metabolismo social (os fluxos de energia e materiais) concomitante ao crescimento econômico. 
RODRIGUES, J. C.

Conflitos territoriais na Amazônia oriental, oeste do estado do Pará: duas situações distintas, mas a mesma lógica imperativa

A perspectiva de Joan Martinez Alier e assim como estudos recentes (FLEURY; ALMEIDA; PREMEBIDA, 2014; RADAELLI; VARGAS; FLEURY, 2019), convergem com a relação sociedade/natureza e algumas perspectivas sobre conflitos, dos quais o capitalismo é protagonista (MIKATI, 2020), apesar das diferenças e diferenciações históricas produzidas. Mas também alinhado as diferenças e diferenciações históricas produzidas é necessário compreender que há processos e relações entre saber e poder, ser e ter, entre submissão (colonialidade) e reconhecimento, entre apropriação e desapropriação (SILVA; ARAÚJO; SILVA, 2019). Como destaca Acselrad (2014), no campo político, nas atuais condições de liberalização dos mercados, têm sido apresentado uma narrativa conciliatória e moderadora, no aspecto preventivo, para justificar fórmulas compensatórias e mitigatórias (ZHOURI, 2018), consequentemente, uma forma de ignorar, desqualificar, condenar ou obscurecer evidências de danos produzidos, que, aliás, não são e não serão mitigados e compensados.

A reflexão de Acselrad (2014) é interessante, pois a configuração de modelos e políticas (neo)desenvolvimentistas (CASTRO, 2017a), principalmente na década de 1990 e 2000, vem contribuindo diretamente no processo de negação e violação de direitos (sociais, humanos, étnicos e ambientais), leis, regulamentações ambientais e territóriadades específicas (ZHOURI, 2015; 2018), no caso conflitos territoriais. Tais conflitos territoriais, visualizados particularmente na Amazônia, com: i) processos de desterritorilização de populações rurais, agroextrativistas, populações e comunidades indígenas, quilombolas e ribeirinhas, provocados pelos grandes projetos desenvolvimentistas (RODRIGUES; LIMA, 2020); ii) deslocamentos forçados por inundações, mudança na qualidade dos recursos florestais, aquáticos, do solo e do ar (racismo ambiental e perda de conforto ambiental) (HAZEU, 2015; CASTRO, 2017a); e, iii) intimidações, ameaças, tentativas de assassinatos, assassinatos e grilagem de terras (CPT, 2020).

Há também uma outra variável subjacente a essas políticas espoliativas desenvolvimentistas, ou como prefere Castro (2017a, p. 36): “[...] processo civilizador e portador do desenvolvimento e do progresso". Segundo Acselrad (2014) observam-se, no continente latino-americano, processos de reconfiguração das lutas por terras em lutas por território e de etnização de parte das lutas territoriais, ambientais e fundiárias (CASTRO, 2018; ZHOURI, 2018). Como destaca Leff (2018, p. 358): “Hoy, los Pueblos de la Tierra no 
RODRIGUES, J. C.

Conflitos territoriais na Amazônia oriental, oeste do estado do Pará: duas situações distintas, mas a mesma lógica imperativa

solo reclaman el reconocimiento a sus modos ancestrales de vida, sino que demandan su derecho de ser: a reinventar sus identidades, a resignificar sus mundos de la vida en una reflexión sobre sus condiciones de existência".

Tal situação de lutas territoriais ocorreriam pelas seguintes motivações: as lutas ou disputas seriam travadas pela apropriação material e simbólica do território, todavia, o processo de disputa (estratégias de resistências) conforma-se pela exposição e legitimação de tipos de capitais e sentidos sociais sobre o (uso do) território. Isso porque há uma profunda assimetria de poder econômico, por exemplo, sobre os estudos de viabilidade de um empreendimento, uma vez que são emitidos pela própria empresa interessada (quando não pelo Estado), por meio de empresas contratadas.

Outra assimetria de poder é a profusão ou difusão em massa de informações nos meios de comunicação e a plataformas e mídias digitais sociais. Então o processo de disputa perfaz-se pela "produção" de: narrativas, contra narrativas, racionalidades e redes hierárquicas de poder ou conquistas simbólicas de parceiros de blindagem e/ou luta, como, instituições de pesquisas (com estudos), associações sociais, trabalhistas, sindicais e ambientais, grupos instituições jurídicas, midiáticas e artísticas, instituições religiosas e espirituais, organizações intergovernamentais e internacionais (ONU, UNESCO, UNICEF, FMI, BIRD, OMS).

Segundo Laschefski e Zhouri (2019), grupos econômicos e políticos hegemônicos criaram as estratégias de despolitização, silenciamentos, desqualificações e criminalização das pessoas atingidas pelos grandes projetos, assim como movimentos sociais e pesquisadores(as) críticos(as). Além disso, o capitalismo liberalizado procura, segundo Acselrad (2014), capturar os atores sociais no interior de "alternativas infernais", isto é, construir situações que parecem não deixar outra escolha além da resignação ou da denúncia impotente ante a guerra econômica incontornável e de uma luta impossível de vencer. Por isso, o intenso processo das lutas territoriais buscarem revalorização das identidades culturais, das práticas tradicionais e saberes originários como forma de proporcionar uma tensão discursiva e comparativa entre a racionalidade instrumental e o saber ambiental (SILVA; ARAÚJO; SILVA, 2019).

Assim, conflitos territoriais, aqui entendidos, não são reduzidos à distribuição de recursos ou ônus de tal ação política e/ou econômica, tão pouco a crítica ou a guerras jurídicas, mas, sobretudo, às formas distintas, sentidos de apropriação e relação com e na natureza e defesa dos territórios como fonte de reprodução social: material, econômica, 
RODRIGUES, J. C

Conflitos territoriais na Amazônia oriental, oeste do estado do Pará: duas situações distintas, mas a mesma lógica imperativa

simbólica, identitária, cultural, religiosa, cosmológica, que pode se manifestar em eventos, dinâmicas ou permanências nos lugares. territórios. Portanto, o fio condutor da compreensão sobre conflitos territoriais passa pela visão e habitus ${ }^{3}$ de grupos sociais que pautam sua visão enquanto coletividade, comunitariedade, reciprocidade, solidariedade, cooperação, espaços coletivos comuns, autogestão e autossuficiência, pressupostos esses rechaçados pela racionalidade instrumental capitalista.

\section{Conflitos territoriais: duas situações distintas, mas com a mesma lógica imperativa}

Cada contexto de tempo põe suas formas e problemas de fundamentos e ideias. E cada mudança de época repõe tais exigências, reafirmando com a atualização ou o perecimento cada campo de conhecimento. Assim, entra-se num período temporal de parâmetros registradores do novo, até que outro tempo novo os revogue. É o que vemos no atual momento (MOREIRA, 2020, p. 107).

A citação de Moreira levanta uma reflexão interessante e importante que seria a de pensar as formas e problemas presentes e emergentes, como também a revogação de tempos e temporalidades. Essa reflexão é importante, pois tanto para Moreira (2020) quanto para nós, aqui neste artigo, é que as mudanças não são/estão reduzidas a transformações da paisagem, mas sim a uma transformação sistêmica: cognição, relações sociais, meio ambiente, políticas, economias, culturas, naturezas e territórios. Transformações essas ocorridas pelas lógicas e racionalidades pautadas: em aspectos econômicos e de mercado, ao mito do progresso, de crescimento econômico linear e baseado na obsessão pelo hiperconsumo material (GUDYNAS, 2011; ACOSTA, 2016).

Presencia-se, na América Latina, e, particularmente no Brasil, a partir da década de 2000, em políticas de crescimento focadas na solução da "pobreza extrema" e nas desigualdades sociais, porém, baseadas na distribuição de renda (e consumo) e não na distribuição de riquezas. Como também são alicerçadas na mercantilização da floresta (serviços ambientais e créditos de carbono), da terra, água, solo e subsolo. Essa configuração é uma dinâmica de especialização econômica e social dos territórios e supressão da diversidade ambiental, etnocultural, econômica, histórica, identitária e intercultural; portanto, sendo a asfixia de outras formas de compreender, pensar, ser, sentir, desejar e apropriar-se de naturezas e territórios (GUDYNAS, 2011; ESCOBAR, 2015; ACOSTA, 2016).

\footnotetext{
${ }^{3}$ Habitus é um sistema de esquemas de percepção, apreciação e ação que estão ligados a um "campo", do qual se reproduz a lógica objetiva de campo, consequentemente re-produzido relações sociais objetivas, os esquemas classificatórios, princípios de classificação, princípios de visão (BOURDIEU, 1997).
}

Revista Cerrados, Montes Claros/MG, v. 18, n. 02, p. 474-511, jul./dez.-2020. 
RODRIGUES, J. C.

Conflitos territoriais na Amazônia oriental, oeste do estado do Pará: duas situações distintas, mas a mesma lógica imperativa

Quando se pensa na escala da Amazônia, visualiza-se um processo impositivo de materialização ou instauração na região de um:

\begin{abstract}
'Tempo veloz' associado à lógica da rodovia, das conexões aeroviárias, dos sistemas de infovias e dos grandes fluxos econômicos, do qual é internalizado nos corpos e mentes das pessoas como um ajuste ou alargamento forçoso nas suas dinâmicas e práticas diárias, pois o "progresso", a instantaneidade, descartabilidade, efemeridade e trabalho esquizofrênico (incessante) seriam encarados como bom, bonito e inevitável (HARVEY, 2008) e "[...] reproduzidas numa espacialidade concretizada e criada, que tem sido progressivamente "ocupada" por um capitalismo que avança, fragmentada em pedaços, homogeneizada em mercadorias distintas, organizadas em posições de controle e ampliada para a escala global" (SOJA, 1993, p.115) e cria novos desejos e necessidades de cunho material (RODRIGUES, 2018, p. 260).
\end{abstract}

Para Rodrigues (2018), tal tempo, "tempo veloz" e "tempo lento", seriam ritmos que muitas das vezes coexistem de forma conflituosa, pois o "tempo veloz" materializa-se nos territórios, por meio de uma "profunda perturbação" (HARVEY, 2008, p. 219), por exemplo, com o inchaço populacional da cidade (com estrangulamento do sistema educação, saúde e proteção social), violência urbana. Além disso, do "caos" no centro da cidade, em virtude do congestionamento, envolvendo: automóveis e motos particulares, mototaxistas, taxistas, ciclistas e caminhões (ao “desembarcarem” mercadorias).

Tais transformações são expressas na dinâmica urbano-rural de Itaituba e região oeste do Pará (RODRIGUES, 2018), na bacia do Tapajós e no rio Tapajós, com um processo de monopolização do(s) território(s) que segue em curso. Seguiriam em curso, pois há: 1) vários projetos portuários (mais de quarenta portos) e; 2) diversas ações, políticas e narrativas de agentes hegemônicos. Ações, narrativas e políticas que precisam ser legitimadas sistematicamente e sutilmente disputadas (ACSELRAD, 2014; ALMEIDA, 2012; CASTRO, 2018; ZHOURI, 2018).

Disputas (territoriais) que podem ver visualizados no rio Tapajós, em Itaituba ${ }^{4}$, com pescadores(as) artesanais, que se expressam em relações de apropriação (assimétricas de poder) e expropriativa de acessar algo, que, segundo Paula (2019; 2020), seria a de acessar os recursos ambientais.

\footnotetext{
${ }^{4}$ As espécies "exploráveis” pela pesca artesanal são: aracus, piaus, tucunarés, jaraqui, pescada branca, surubim, acará, pacu, mapará, fura-calça, branquinha e sarda (ZACARDI; PONTE; SILVA, 2014).

Revista Cerrados, Montes Claros/MG, v. 18, n. 02, p. 474-511, jul./dez.-2020.
} 
RODRIGUES, J. C

Conflitos territoriais na Amazônia oriental, oeste do estado do Pará: duas situações distintas, mas a mesma lógica imperativa

\title{
Disputas e apropriação do território: conflitos com os(as) pescadores(as) artesanais
}

Essa disputa territorial "inicia-se" com a "contagem" (questionamento) de pescadores(as) artesanais. Algo que veio ocorrer com a licença de operação (n. 8677) concedida no dia 19 maio de 2014, ao porto da Bunge (recentemente Unitapajós), o qual reduziu a atividade pesqueira nas imediações dos empreendimentos a apenas dois pescadores, o que pode ser visualizado na nota técnica 1973/GEINFRA/CLA/DILAP/2015, da Secretaria de Estado de Meio Ambiente e Sustentabilidade (SEMAS). Tal estratégia de disputa territorial é algo recorrente de grandes projetos e políticas territoriais sobre Amazônia, que a considera como espaço de "vazio demográfico", assim como promotora da invisibilização e da negação do outro e suas territorialidades ${ }^{5}$ (RODRIGUES; LIMA, 2020).

Porém, o estudo de Zacardi, Ponte e Silva (2014) ${ }^{6}$, na Colônia de pescadores Z56, apontava que havia 889 pescadores cadastrados (homens e mulheres), dos quais 60\% atuavam em tempo integral no setor; tendo uma produção mensal de pescado que variava em média entre 50 a $800 \mathrm{~kg}$. Além disso:

\begin{abstract}
Na comunidade de Miritituba, as mulheres exercem papel importante na pesca, pois, junto com maridos e filhos dividem as funções da atividade pesqueira, como: pilotagem das embarcações, retirada dos peixes emalhados, eviscerar e "ticar" os peixes e são as principais responsáveis pelos consertos das redes de pesca, caracterizando a identidade da família enquanto pescadores artesanais. Percebe-se, portanto, que a unidade de produção da pesca corresponde, na maioria das vezes, à unidade familiar (ZACARDI; PONTE; SILVA, 2014, p. 137). [...] Observou-se que quando a unidade de produção é formada por relações de vizinhança e parentesco distante, a pesca neste caso, constitui-se uma sociedade de co-participação, as relações de trabalho não são formais e não existe assalariamento. A divisão da produção ocorre no sistema de partes, por meio de acordos entre os participantes (ZACARDI; PONTE; E SILVA, 2014, p. 138).
\end{abstract}

Há com isso uma forte dependência econômica, social e simbólica na atividade pesqueira. Atividade, aliás, que sofreu um forte abalo com o início da operação da Bunge

\footnotetext{
${ }^{5}$ Ministério Público Estadual e Federal em Ação Civil Pública questiona: (a) que não houve consulta prévia, livre e informada (com relação aos portos da Bunge, Hidrovias do Brasil e Cianport) (d)as aldeias indígenas da Praia do Índio, Praia do Mangue, Sawré-Muybu, e demais populações tradicionais, como a de Montanha e Mangabal, ribeirinhos, pescadores, garimpeiros artesanais, localizados na área de influência do empreendimento projetado e afetados pelas medidas administrativas e legislativas já executadas no âmbito do licenciamento ambiental.

${ }^{6} \mathrm{O}$ trabalho foi publicado em 2014, mas as coletas de dados ocorreram em 2012. A data aqui é importante, pois a pesquisa precede a instalação do Porto da Bunge (recentemente Unitapajós), que começou a operar em 2014. Revista Cerrados, Montes Claros/MG, v. 18, n. 02, p. 474-511, jul./dez.-2020.
} 
RODRIGUES, J. C

Conflitos territoriais na Amazônia oriental, oeste do estado do Pará: duas situações distintas, mas a mesma lógica imperativa

(hoje denominado Unitapajós, joint venture com o Grupo Amaggi), em seguida com os portos do grupo Cianport, Hidrovias do Brasil, Cargill e Transportes Bertolini/ADM, como assinala o presidente da Colônia de Pescadores de Itaituba - Z-56, Francisco Coelho (o Tucuruí) (em entrevista), em 2017:

Bom a pesca ela teve mudança assim ... perca de espaço ... naquele setor ali onde foi construído os portos... e também vão ser ainda construído alguns ... ele era pesqueiro ... porque fala que perdeu espaço ... de duas maneiras nós perdemos o espaço ... por motivo de construção dos portos e também perdemos espaço no setor onde as barcaças passam que são os leitos do Tapajós ... e também porque eles essas balsas elas são apoitadas no meio do Tapajós por exemplo ... uma empresa tem um porto lá na frente do porto dela lá a 100 metros 200 metros beirando o canal eles colocam uma boia ... e lá eles vão ... ancorar essas barcaças ... e aí a gente perdeu aquele espaço da bubuia ninguém pode bubuiar mas adorado filhote ... ou mesmo outro peixe de espécie que a gente pescava ... e na margem do rio que é a barrigueira ... porque o pescador pesca no tempo do cardume ... por exemplo chegou o tempo do aracu da lua de maio que a água começa a vazar ... todos nós tínhamos nosso setor de pesca ... eu tinha cinco seis pesqueiros ... naquele trecho ali onde era (Bunge) ... abaixo da bunge ali começava o sabá ... tinha dez grupos pesqueiros terminava ai tinha o Raimundinho e assim por diante ali com aqueles pesqueiros ... a gente pescava do período de maio até fim de julho ... que era a derradeira boa do aracu ... após a construção não era que eles impeçam a gente de pescar ... eles impedem só onde tá construído a obra ... mas em compensação você não vai poder colocar a rede em lugar nenhum ... porque ali tem o movimento das barcaças ... entra sai então você fica impedido de por as malhadeiras de qualquer maneira esse foi um dos maiores prejuízos.

Francisco Coelho ainda reitera acerca da proibição da pesca - que seria perda de

territórios, ao longo e na frente dos portos e em situação de proibição da atividade pesqueira:

Sim, e não só a BUNGE eu acho que a BUNGE é a única que não perturba tanto ... hoje nós já temos outras empresas que tão operando ... nós já temos a Hidrovias ... temos a Cargill ... temos a:: Bertolini que não tá no porto dela mas tá operando na doca ... e.: ... segundo relato de pescador que eles falam com a gente né ... que eles cobram que não podem pescar naquela área ... por medida de segurança né ... outra coisa a marinha também demarcou a área que eles não podem ficar ... então isso pra nós a gente tem um pouco de complicação ... porque a gente não foi avisado disso ... então antes deveria reunir com as colônias fazer uma reunião com os pescadores ... essa reunião fosse destinada aos pescadores ... pra que eles pudessem ficar cientes do que ia acontecer após a construção né ... porque aquelas áreas são áreas de marinha né ... patrimônio da União né ou já venderam tudo né ((risos)) e o:: pescador ... ele tem uma carteira ... essa essa carteira dá direito como pescador artesanal em todo o território nacional ... tá que não seja área indígena e área reserva ... e:: nós ainda não saímos nem da nossa jurisdição que tá na frente da nossa cidade ... e já não podemos mais fazer o que é de direito que é a pesca ... então essas são as coisas que a gente fica complicado com isso né fica preocupado ... o que vai ser de nós futuramente ... a gente vê que o governo imprensa as empresas vão imprensando e o que a gente tá vendo é que futuramente não teremos mais a pesca artesanal né ... [...] ... então vai chegar uma hora que o pescador vai ter que abrir um buraco pra colocar a malhadeira dele ali dentro porque todo lugar é proibido dele pescar.

Revista Cerrados, Montes Claros/MG, v. 18, n. 02, p. 474-511, jul./dez.-2020. 
RODRIGUES, J. C.

Conflitos territoriais na Amazônia oriental, oeste do estado do Pará: duas situações distintas, mas a mesma lógica imperativa

Cabe destacar que, desde a concessão de licença (licença prévia), para a empresa Bunge (hoje Unitapajós), houve negação da atividade pesqueira, invisibilização de tais trabalhadores(as) e territorialidades e a redução da atividade pesqueira nas imediações dos empreendimentos. Negação da atividade pesqueira e invisibilização de pescadores(as), visualizado: no Estudo de Impacto ambiental (EIA), no Relatório de Impacto Ambiental (RIMA) e na licença ambiental (Licença Prévia) do Porto da Bunge. Na licença n. 1964, em 25 maio de 2012, concedida à Bunge (com o nome, naquele momento, de Rio Turia Serviços logísticos), não houve nenhuma "referência" a programas ou ações mitigatórias advindas de efeitos negativos à comunidade pesqueira, no caso, pescadores(as) artesanais.

Com relação em si, a perda desses "territórios pesqueiros", ocorreu um sério problema, pois dialogando com o trabalho de Zacardi, Ponte e Silva (2014, p. 142):

\begin{abstract}
Independente da arte de pesca empregada, este estudo apresenta um forte componente territorial relacionado a localização geográfica da comunidade às margens do rio, onde residem estes pescadores e por estar situada em frente à sede do município, Itaituba. Desta forma, concentram suas pescarias, preferencialmente, nas margens do rio Tapajós, lagos e igarapés do entorno, por serem áreas de pesca menos onerosas, sem necessidade de utilização de gelo e baixo consumo de combustível.
\end{abstract}

Apesar de pontuarmos acima a perda de território físico, com a construção de muros/cercamentos invisíveis promovidos pelos portos, isso representa na realidade um conflito territorial, isto é, uma luta política, envolvendo grupos sociais com modos diferenciados de territorialidades/temporalidades, de apropriação, uso e significação/sentido de território, que não se reduz ao acesso a recursos ambientais (PAULA, 2020). Assim os territórios pesqueiros seriam configurados como "mundos" e lógicas (muito) distintas, simbolicamente construídas e conservadas.

Segundo Laschefski (2011, p. 129), “[...] a luta pela apropriação da natureza não consiste na disputa por espaço meramente físico, livre de qualquer sentido. O conflito se estabelece em torno de espaços preenchidos por diferentes significados culturais, ou seja, em torno dos territórios". Essa compreensão do autor ganha mais sentido quando também se compreende territórios tradicionais dos(as) pescadores(as) artesanais, como um lugar de viver e sobreviver e como expressão de "relações comunitárias e com a natureza, sendo fundamental na reprodução social, cultural e econômica das comunidades" (PAULA; SUERTEGARAY, 2018, p. 108). 
RODRIGUES, J. C.

Conflitos territoriais na Amazônia oriental, oeste do estado do Pará: duas situações distintas, mas a mesma lógica imperativa

Portanto, há disputas (conflitos) pelo controle e a apropriação dos benefícios materiais e/ou produtos simbólicos do território (no caso, o rio) e com as constantes negações de territorialidades preexistente (PAULA, 2020). Isso é destacado na fala de Francisco Coelho (o Tucuruí), em entrevista:

\begin{abstract}
- Tão tirando areia de um lugar ... pra tampar um buraco e deixando outro ... tão usando os pescadores né ... massacra o pescador ... e facilita a vida do homem que tá em terra por exemplo em Miritituba ... um monte de gente que trabalha ... mas o pescador não se emprega. Falei pra ele [membro da ATAP/AMPORT ${ }^{7}$ ] "se o pescador se empregar a carteira dele é cassada" ... e aí você desemprega o pescador e emprega o fulano de tal porque na verdade quem tá sentindo os impactos é o pescador porque você tá tirando o direito deles de pescar ... (entrevista em 2017).

- Já fui em várias reuniões deles [da AMPORT]. Nunca vim sair nada, nada da... da, como é se diz que se diga assim que não estamos vendo a luz no fim do túnel que possa compensar o projeto para pesca. Como gente discuti aqui os portos. Olha a empresa não empata pescar. [...] [Porém] Chega lá marra sua malhadera e bota pra fora. Mas na hora que cara dá acelerada no rebocador lá.... Então não é preciso empatar você pescar. Não é mais conveniente pescar. - Você sabe quanto tempo pesquei ali onde era Bunge [hoje porto Unitapajós], 26 anos (entrevista dezembro de 2019).
\end{abstract}

É preciso enfatizar que essa disputa, entre pescadores(as) artesanais e empresas, podem conduzir ao estilhaçamento daquilo que fala Paula (2020, p. 182) de "malha territorial": a "malha territorial na pesca artesanal é composta por uma ampla área que integra pesqueiros, área de moradia e de vivência, e mercados locais". Além de contribuir para a construção de uma "insegurança" em termos: i) de soberania e risco alimentar e nutricional para pescadores(as), para a cidade e para a região; e, ii) de geração de renda e de permanência na área de moradia. Contribuindo ainda para o comprometimento de territorialidades específicas desse grupo social tradicional.

Isso seria importante já que como enfatiza Paula e Suertegaray (2018), o processo modernizador se impõe sobre territórios, negando a história dos lugares, dos sujeitos sociais, da tradição, da cultura e da economia local. Assim como direitos, por exemplo, com a negação da Lei $\mathrm{n}^{\circ}$ 11.959, de 29 de junho de 2009, que dispõe sobre a Política Nacional de Desenvolvimento Sustentável da Aquicultura e da Pesca, que é responsável por "regular" as atividades pesqueiras, cujo objetivo primordial é: o desenvolvimento socioeconômico,

\footnotetext{
${ }^{7}$ Associação dos Terminais Portuários e Estações de Transbordo de Cargas da Hidrovia do Tapajós (ATAP). A partir de agosto de 2016, a ATAP torna-se Associação dos Terminais Portuários e Estações de Transbordo de Cargas da Bacia Amazônica (AMPORT) que representa 12 empresas que possuem: Cargill, Cianport, Hidrovias do Brasil, Imerys, LDC, Mineração Buritirama S.A, Norsk Hydro S.A, Chibatão Navegação, Terminal de Grãos Ponta da Montanha, Termogás S/A, Transportes Bertolini e Unitapajós.
}

Revista Cerrados, Montes Claros/MG, v. 18, n. 02, p. 474-511, jul./dez.-2020. 
RODRIGUES, J. C.

Conflitos territoriais na Amazônia oriental, oeste do estado do Pará: duas situações distintas, mas a mesma lógica imperativa

cultural e profissional dos que exercem a atividade pesqueira, bem como de suas comunidades (art.1, parágrafo 4).

Há outro conflito territorial ocorrendo em decorrência da produção de complexos portuários, da territorialização do agronegócio, na Comunidade de Santarenzinho, a partir de uma ruptura abrupta com o lugar ontológico relacional.

\section{Conflitos territoriais na comunidade de Santarenzinho}

A comunidade de Santarenzinho encontra-se localizada na margem direita do rio Tapajós, distante aproximadamente $18 \mathrm{~km}$ da sede do município de Itaituba, e mais de 130 km da sede do município de Rurópolis. Essa comunidade foi fundada no final do século XVII por exploradores da região; inicialmente levou o nome de "Uxituba". Tal comunidade está dentro do Assentamento da Reforma Agrária chamado Araipacupu, criado em 21/11/2006, pelo Instituto Nacional de Colonização e Reforma Agrária (INCRA). Assentamento esse que possui mais de 30 mil hectares e 361 famílias assentadas. A comunidade de Santaerezinho é formada por quatro famílias: Vajão, Menezes, Galvão e Silva, onde residem aproximadamente vinte famílias (oitenta pessoas), porém já tinha chegado a sessenta famílias (afirmação baseada nas entrevistas) (Figura 1).

Figura 1: Fotografias da comunidade de Santarenzinho, oeste do estado do Pará
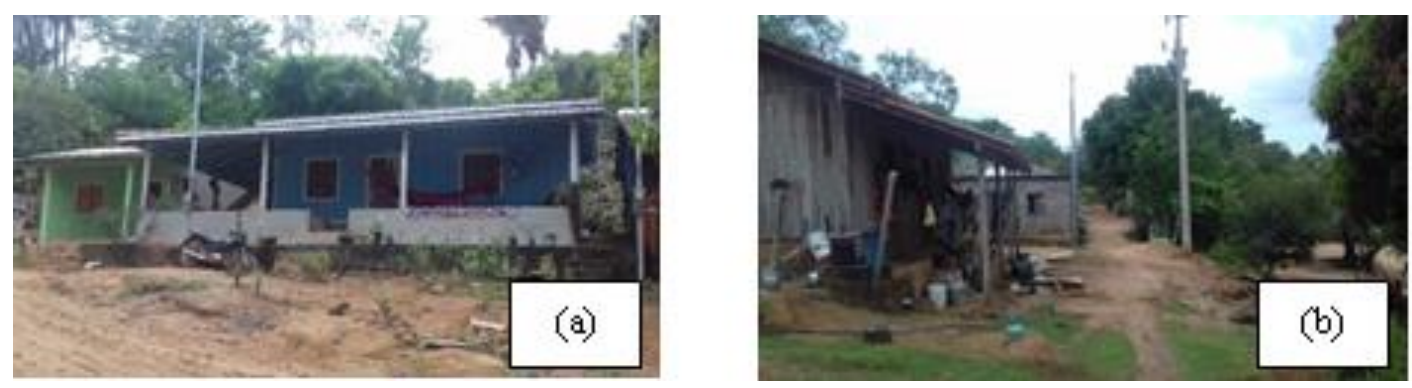

Fonte: Fotos (a) e (b) dia 8 de dezembro de 2019

Santarenzinho constitui uma comunidade tradicional, principalmente porque se configura como uma “[...] organização social, que ocupa e usa territórios e recursos naturais como condição para sua reprodução cultural, social, religiosa, ancestral e econômica, utilizando conhecimentos, inovações e práticas gerados e transmitidos pela tradição" 
RODRIGUES, J. C.

Conflitos territoriais na Amazônia oriental, oeste do estado do Pará: duas situações distintas, mas a mesma lógica imperativa

(BRASIL, 2007). Além disso, guardam um patrimônio histórico cultural, "um sítio arqueológico", no qual segundo Rocha et al (2014), a identificação de sítios arqueológicos é creditada em grande parte ao conhecimento territorial das comunidades tradicionais que integram paisagens antropizadas de longa duração.

O sítio arqueológico possui cerâmica e artefatos de origem indígena (no Museu Vovô Affonso), de indígenas de várias etnias, principalmente da etnia Munduruku. Constituise, portanto, "terras tradicionalmente ocupadas" (ALMEIDA, 2004), que se expressaram e se expressam historicamente por meio de uma gama de diversidades e "[...] formas de existência coletiva de diferentes povos e grupos sociais em suas relações com os recursos da natureza" (ALMEIDA, 2004, p. 9). Muitas das relações ou territorialidades específicas pautadas na ideia do pluriverso, isto é, na coexistência de muitos mundos e com diversas e emaranhadas cosmologias (ESCOBAR, 2015).

Essa comunidade, a partir de 2011, começou a sofrer pressões com relação à sedução por dinheiro e venda de terras (com especulação já em 2010), e consequentemente o rompimento de vínculos comunitários: “[...] aí como a ... venda começou em 2011 aí 2012 né ... até a:: agora que parou um pouco /.../ já tem alguns anos que não vende mais nada né desde 2013 parece que [...] estão presos né ... essa:: rouba-lheira né"8 (João Carlos ${ }^{9}$, Morador de Santarenzinho, entrevista gravada em maio de 2016).

Essa especulação fundiária foi intensificada, a partir de 2016, quando houve uma padronização do preço dos terrenos:

[...] agora que o certo certo certo mesmo é que aqui na região que foi estipulado mesmo é cem mil um hectare de terra ... aqui ... eles fizeram tipo assim né você é diz aqui o preço por hectare ... cem mil um hectare

[...] chegaram num acordo né porque tá ficando muito especulativo e não dá conta chegaram assim.

[...] ficou ... tava em torno disso ... cem mil à hectare ou seja um terreno que tem dez hectares dá dez milhões ... se ele dá trinta hectares trinta milhões ... só que é assim como eu tô falando ... isso depende do local né tem local que é mais caro do que outro esse terreno mesmo nosso pelo valor que ele ofereceu iria girar em torno de quase duzentos mil reais à hectare ... (José Maria, Morador de Santarenzinho, entrevista gravada em setembro de 2017).

Em 2011 era um contexto de avanço de agentes econômicos e investimentos com o objetivo de produção de complexos portuários para movimentação de grãos, portanto, para

\footnotetext{
${ }^{8}$ É uma referência ao grupo Odebrecht.

${ }^{9}$ Por uma questão de ética e preservação do nome dos entrevistados, criamos nomes fíctícios. Revista Cerrados, Montes Claros/MG, v. 18, n. 02, p. 474-511, jul./dez.-2020.
} 
RODRIGUES, J. C.

Conflitos territoriais na Amazônia oriental, oeste do estado do Pará: duas situações distintas, mas a mesma lógica imperativa

agronegócio (RODRIGUES; RODRIGUES, 2015; RODRIGUES, 2018); ao mesmo tempo havia uma disputa na esfera do poder público, Itaituba e Rurópolis. Uma disputa jurídica entre município de Rurópolis e Itaituba acerca de quem "pertenceria" a Santarenzinho.

O município de Itaituba, a partir de $2016^{10}$, por meio da Procuradoria Geral do Município (PGM), acionou a justiça federal, por meio de uma medida cautelar para que fosse realizada uma perícia, "in loco", para definir/delimitar o limite territorial entre os dois municípios, e a quem "pertenceria” Santarenzinho (ainda à espera de decisão), pois hoje figuraria como "pertencente" ao município de Rurópolis. Tal conflito territorial, dialogando com Fonseca (2020), envolvendo os limites municipais, estão articulados à globalização e aos jogos de interesses específicos, locais e regionais, para captura de investimentos volumosos sobre territórios, assim como por tributos.

Essa disputa constitui uma forma de capturar capital simbólico e econômico (financeiro e/ou “compensações”) para o poder público e elites locais. Seria uma busca por "beneficios materiales o simbólicos de universalización (los mismos que persiguen las estrategias dirigidas a "ponerse en regla") y que los universos que, como el campo burocrático, reclaman con la mayor insistencia la sumisión a lo universal" (BOURDIEU, 1997, p. 124). Em síntese seria a monetização simbólica da comunidade, acompanhada da asfixia e a mutilação de crenças, tradições, valores, sociabilidades/territorialidades específicas, ou seja, a redução da comunidade ou o território a um ato de troca.

Essa monetização, que é também econômica (KOTHARI et al. 2020), da comunidade pelos grandes agentes econômicos e pelo Estado (que também é um agente econômico) reverbera-se no território (ZHOURI, 2018), na comunidade tradicional: na fragmentação familiar e no conflito territorial. Em "entrevista" com um morador e membro da associação comunitária de Santarenzinho, há um destaque sobre a fragmentação familiar (quando da fala sobre venda de terrenos):

[...] porque foi assim ... teve o terreno que foi vendido ali pra são dois donos ... esse terreno que também era da minha tia aqui também virou em dois ... então com isso assim desparcelou um pouco as famílias que tinham aqui venderam e aí eles é:: as terras não eram pequenas a deles ... de irmãos por exemplo aí eles venderam e se tornou em dois donos três assim que é:: que ficou aqui ... houve uma divisão de terras ... que as vezes tinha um dono vendeu ele ele tinha dois documentos né ... aí

\footnotetext{
${ }^{10}$ No dia 11 de novembro de 2016, realizou-se uma audiência pública na câmara de vereadores de Itaituba, para discutir acerca do problema da divisa de Itaituba com Rurópolis, mais especificamente, o caso de Santanrenzinho.
} 
RODRIGUES, J. C.

Conflitos territoriais na Amazônia oriental, oeste do estado do Pará: duas situações distintas, mas a mesma lógica imperativa

surgiu ficou em dois donos que o caso de bem aqui ... que era do Waltinho/Valtinho hoje tem dois donos ... lá que era da minha irmã também virou vai ser dois donos ou já é .... então ... se tornou assim ... é:: em vez de uma empresa tá duas três [Negrito nosso] (João Carlos, Morador de Santarenzinho, entrevista gravada em maio de 2016).

[...] elas saíram exatamente por::: é::: vendas de terra essa coisas e foi vendendo vendendo vendendo e foi saindo aí ... outros que moravam aqui[...]... e hoje já não é mais assim devido a venda de terras e:: ... as pessoas sempre olham o dinheiro né ... e:: não sei porque mais muitas pessoas olham assim mesmo que não que tenham um prejuízo muito grande depois mas sempre ter aquele dinheiro né ... que deu eu pelo que percebeu já deu prejuízo pra muita gente já isso

[...] vendido tem mais ou menos uns quinze lotes vendidos.

[...] o mais caro saiu em torno de dois milhões e meio ... dois e meio mais só perdem é:: trinta hectares ... humm pequena mas trinta hectares (José Maria, morador de Santarenzinho, entrevista gravada em setembro de 2017).

Esse "desparcelou" traz consigo uma densidade reflexiva, pois associa a comunidade como uma grande família. A venda dos terrenos significou a fragmentação de uma família, após seus "parentes” terem vendido suas terras para construção de portos (foram cinco núcleos familiares - no total mais de quarenta pessoas que moravam e venderam as terras) e ainda familiares que possuem o interesse de vender suas terras.

Essa compreensão de vínculo social de "morador" vai de encontro com a

[...] Su forma dominante, esta modernidad - capitalista, liberal y secular - ha extendido su campo de influencia a la mayoría de rincones del mundo desde el colonialismo. Basada en lo que llamaremos una 'ontología dualista' (que separa lo humano y lo no humano, naturaleza y cultura, individuo y comunidad, 'nosotros' y 'ellos', mente y cuerpo, lo secular y lo sagrado, razón y emoción, etc.),

[...] "Un Mundo" - que hoy llega a su máxima expresión con la llamada globalización neoliberal de corte capitalista, individualista, y siguiendo cierta racionalidad - ha conllevado la erosión sistemática de la base ontológica-territorial de muchos otros grupos sociales, particularmente aquellos donde priman concepciones del mundo no dualistas (ESCOBAR, 2015, p. 93).

Essa globalização neoliberal/financeira, por meio de agentes econômicos (empresas, multinacionais e Estado), tendem, dialogando com Bourdieu (2014), a aplicar de forma sutil às estruturas objetivas (estruturas de percepção, ação e apreciação), no mundo social para que ele se movimente, consequentemente, contribuindo para que territórios e pessoas também se movimentem (física e mentalmente). Tal situação seria na realidade "coações" (violência simbólica), cujas pessoas reunidas iriam se modelando a código de regras e regularidades (BOURDIEU, 1986).

Esses códigos de regras e regularidades vêm sendo expressos em conflitos familiares - entre famílias -, uma espécie de modificação da estrutura de sentimento de família 
RODRIGUES, J. C.

Conflitos territoriais na Amazônia oriental, oeste do estado do Pará: duas situações distintas, mas a mesma lógica imperativa

e coletividade, por uma das famílias ${ }^{11}$. Além disso, insere-se uma visão de "tempo veloz", de hiperconsumo, crescimento econômico, com o sufocamento de territorialidades específicas a uma vida com tranquilidade, vinculada às temporalidades e ao fluxo do rio, da floresta, da reprodução frutos e animais (GUDYNAS, 2011; ACOSTA, 2016).

João Carlos, morador de Santarenzinho, em entrevista gravada em setembro de 2017, fala sobre o início do conflito:

bom iniciou depois da ... daí da da ... daquele movimento de compra de terreno pra porto né ... esses:: empreendimentos grandes quando eles começaram ... e que é que acontece ... a comunidade era:: uma comunidade simples mas muito organizada ... aí ... já passou a ter conflito dentro porque:: essa área o qual a gente se refere né ela é dentro de uma propriedade né ... e esses proprietário acharam que com isso aí eles não venderiam as áreas deles (José Maria ${ }^{12}$, morador de Santarenzinho, entrevista gravada em setembro de 2017).

Conflito esse que a priori foi a ruptura do senso de coletividade ou de um bem comum coletivo, propriedade comum, pois a escola, centro comunitário, igreja e campo de futebol que foram construídos pela comunidade, que se localizava na propriedade de um familiar em particular (logo adiante exporemos a perda dessa propriedade comum). Tudo isso corresponderia a um processo de, segundo Gudynas (2011, p. 11), “invasión o usurpación, no sólo de recursos naturales, sino de los estilos de vida", com base de desestruturações físicosimbólicos, isto é, o desmoronamento de todas as representações, crenças, tradições, experiências e memorias contidos nesses "objetos" que contribuem para quebrar uma vinculação profunda com o lugar, no caso com o território. Tornando, posteriormente, tais territórios mero valor de troca econômica ou de prestação de serviços econômicos hegemônicos.

[...] eu to com mais de sessenta anos quando eu me entendi que já tinha já tinha essa comunidade ... eu ajudei a construir o que tem hoje no caso o colégio da época eu era o presidente da comunidade ... e hoje eles querem acabar destruir botar tudo no chão pra nós ajuntar os pedaços e fazer me outro lugar esse que é o problema -- mas é como meu irmão disse quem fez foi até ele essa casa é ele quem faz quem construiu a sede [centro comunitário] ... tudo foi ele aí ele disse como é que nós vamos (primeiro) derrubando hoje eu vou ajuntar esses cacos que nós suemos aos pouquinho pra pegando aos pouquinhos comprando brasilite comprando cimento um tijolo pra fazer e hoje nós vamos derrubar e pegar pra fazer de novo não é assim facin que faz né?

(João Carlos, morador de Santarenzinho, entrevista gravada em maio de 2016).

\footnotetext{
${ }^{11}$ Por questão ética e para não desencadear outros conflitos, resolvermos não citar a família especificamente.

${ }^{12}$ Por uma questão de ética e preservação do nome do entrevisto, criamos um nome fictício.
}

Revista Cerrados, Montes Claros/MG, v. 18, n. 02, p. 474-511, jul./dez.-2020. 
RODRIGUES, J. C.

Conflitos territoriais na Amazônia oriental, oeste do estado do Pará: duas situações distintas, mas a mesma lógica imperativa

Quando realizamos essa entrevista, em maio de 2016, já tinham ocorrido várias situações de "brigas" e questionamentos acerca da retirada ou remoção do centro comunitário, igreja, escola, poço artesiano e campo de futebol, e, em final de 2016, houve um pequeno incêndio no clube de futebol (que foi rapidamente contido). Outros sentidos e territorialidades emergiam e passam a vigorar ou compor outras territorialidades que sustentam outras formas de ações sociais e políticas, como assinala Zhouri (2007; 2015; 2018) e Acselrad (2014) seria a construção de relações de poder entre os sujeitos sociais, pautadas e determinadas por outros significados de meio ambiente, espaço e território.

Em setembro de 2017, quando fomos realizar uma nova pesquisa de campo (entrevista, registro fotográfico e conversa com os/as moradores/as), o resquício de afetividade, solidariedade e vínculo social familiar tinha se dissolvido. O cenário de conflito territorial intensificou-se com novos projetos portuários e uma forte busca pela compra de terras por empresários, nacionais, regionais e locais, principalmente com fins especulativos. Segundo Zhouri (2015), há um padrão hegemônico de construção de um pensamento, do Estado e das empresas (empresários públicos e privados), em diversos megaprojetos, que é inserir a "terra como propriedade", e, portanto, como uma mercadoria valiosa (ZHOURI, 2018), sem conteúdo simbólico, identitário, cultural e coletivo.

Tal padrão hegemônico, "terra como propriedade", começava a permear as territorialidades da comunidade, promovendo desestruturações e conflitos dentro da comunidade ribeirinha, sobretudo, porque a "terra" é compreendida como patrimônio comunitário e familiar, de uso coletivo de recursos (da paisagem e socialmente construídos). Portanto, a terra é compreendida como território, isto é, uma expressão de luta, conquistas, de memória coletiva, de identidade e coesão social da comunidade: um "território como símbolo, valor simbólico ("abrigo", "lar", segurança afetiva, fonte de vida, de existência e reprodução social)”(GONCALVES; RODRIGUES; SOBREIRO FILHO, 2019, p. 95).

A intensificação das desestruturações dentro das comunidades ribeirinhas reverberou-se na sequência de atos violentos:

[...] o incêndio ... foi ... no finalzinho do ano passado né em dois mil::: e dezesseis né ... foi em dois mil e quinze finalzinho de dois mil e quinze ... no último dia do ano ... botaram hum é botaram fogo em tudo né mas o fogo não foi pra frente apagou ... e alguém chegou lá zerou ... mas ... quando foi ano passado de dois mil e dezesseis ... é no dia:: vinte e três de julho ... aí derrubaram tudo né que era nosso derrubaram a igreja ... derrubaram a:: sede do clube .. a cozinha aí né o que que a gente tinha de 
RODRIGUES, J. C.

Conflitos territoriais na Amazônia oriental, oeste do estado do Pará: duas situações distintas, mas a mesma lógica imperativa

\begin{abstract}
bem ... aí derrubaram e foi já em setembro pelo dia sete de setembro ... aí os meninos foram brincar no campo de futebol né chegaram lá aí ... já encontraram ... só vidro né ... no campo de futebol ... aí ... lá encerrou o esporte ... sete de setembro não tem mais ... e:: a gente teve muita coisa boa né no passado e hoje nada ... quando passou ... essa fase aí ... de derrubada vidro e tudo né ... aí a gente é::: não conseguiu ... sucesso em nada mais de justiça de nada e tava como você vê tá do mesmo jeito e ... ninguém apenas ninguém faz nada ... e a gente até tem medo de procurar ... a justiça mesmo mas assim forte a gente tem medo pois quando a pessoa faz um ato daquele ... é::: ... a gente tem medo que faça com qualquer um né é:: possível fazer ... como vocês acabaram de ver né tá tudo no chão (a pessoa já tem) quando você ... é capaz ... derrubar uma igreja ... né ... você tem você imagina o que é derrubar uma igreja? [...]

[...] quando foi agora em julho pelo meio do mês de julho foi derrubada a escola as mesmas que derrubaram a comunidade as coisas da comunidade foram as que derrubaram. [...] (José Maria, morador de Santarenzinho, entrevista gravada em setembro de 2017).
\end{abstract}

A destruição da escola, sede de futebol (também sede do centro comunitário), igreja, e do campo de futebol (com cacos de vidros quebrados) (vejam algumas fotos: escola, igreja, sede e nova escola improvisada - Figura 2) vem significar a fragmentação do senso de bem coletivo conquistado e construído mutualmente. Segundo Escobar (2015), a fragmentação do lugar é necessária e indispensável, pois não é possível inserir ou legitimar uma ordem hegemônica e exterior ao lugar (LEFF, 2015; ESCOBAR, 2019), onde homens e mulheres, jovens e adultos, criam e recriam suas práticas, costumes, crenças, tradições, identidades, do qual o território se constitui como lugar de vida. Isso se traduziu na absorção de dores e/ou sofrimento social, isto é, "[...] uma construção coletiva que, por um lado, se exprime na constituição de atores, na construção de uma memória e de uma narrativa sobre um acontecimento" (MAGALHÃES, 2007, p. 261).

Segundo Bourdieu (2003), pessoas que sofrem fortes contradições internalizam uma grande quantidade de sofrimento social, no semblante, no olhar, no corpo e na autoestima. Situação que se refletiu nas crianças e adolescentes, com destruição desses espaços de sociabilidade, conhecimento e fonte de conquista coletiva da comunidade. Assim, os efeitos da territorialização do agronegócio, também produziram uma sobreposição ou amalgamento de efeitos, como um sovar (amassar bem, para tornar homogêneo e liso), no qual o sofrimento social de moradores(as) e crianças da comunidade de Santarenzinho é um exemplo, uma expressão.

Esses efeitos não se assemelham, em termos de singularidades, em sistematizações de pesquisas, mais recentes, acerca da construção e expansão dos empreendimentos portuários no Brasil e seus efeitos territoriais, conforme visualizamos em 
RODRIGUES, J. C

Conflitos territoriais na Amazônia oriental, oeste do estado do Pará: duas situações distintas, mas a mesma lógica imperativa

Vieira (2015), Monié (2016), Moretti e Cox (2016), Gómez-Soto e Silva (2017), Vieira, Leal e Lemes (2017), Sant'ana Júnior, Lopez e Pedro (2019) e Cruz e Hazeu (2020).

Figura 2: Fotografias da escola (A), igreja (C), sede derrubada (D), a nova escola improvisada (E e F) e também a fotografia da escola, antes da destruição (B).

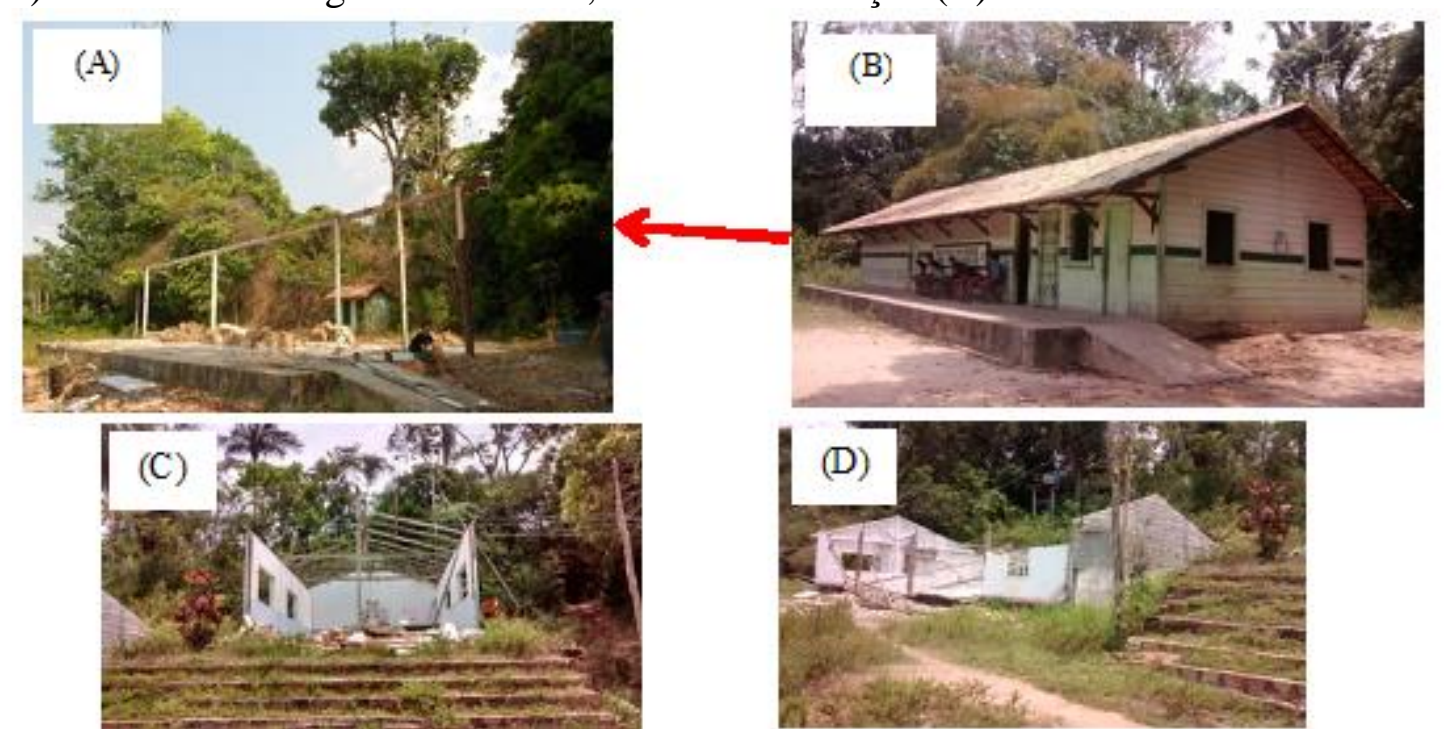

Fonte: As fotografias (A) registradas por Jane Silva/IBASE e as fotografias (B), (C) e (D) registradas por Elmara Guimarães/CPT-Prelazia de Itaituba (fotografias registradas em setembro de 2017). Pesquisa de campo integrada.

Essas destruições, que são, aliás, "despossessões bárbaras”, seriam mecanismos de construção de território como troca. Mecanismo esse que vem se reproduzindo na Amazônia como apontado por Hazeu (2015), em Barcarena/Pará, onde há a sistemática estratégia de jogar famílias contra famílias, seja pela oferta de dinheiro (e brigas por heranças), seja pela contratação de membros familiares para trabalhar na futura empresa, ou, pela compra coletiva da propriedade.

Os agentes econômicos (Estado e empresas) vêm construindo a narrativa (e retórica) de sacrifício social individual para o bem coletivo, do município, da região e/ou do Estado-nação. Na compreensão dessa narrativa os interesses egoístas devem ser superados, principalmente o ritmo do espaço-temporal corporal e subjetivo pautado na velocidade dos rios, florestas, cosmologias, tradições e crenças e inserindo-se a instantaneidade, a modernidade, ao trabalho esquizofrênico e ao desenvolvimento econômico capitalista. Tal narrativa fortalecedora e legitimadora de discursos e imaginários de superioridade de saber e poder (RODRIGUES; LIMA, 2020) como também da monamentalidade do caminho "imperialista" que se pauta-se na narrativa de consumo da modernidade que é de 
RODRIGUES, J. C.

Conflitos territoriais na Amazônia oriental, oeste do estado do Pará: duas situações distintas, mas a mesma lógica imperativa

colonialidade, "progressista e correspondem à retórica celebratória da modernidade" (MIGNOLO, 2017a, p. 4), (o relato da salvação, progresso e felicidade) que justifica[ria] a violência da colonialidade. Para Mignolo (2017b, p. 13) pondera que a colonialidade seria uma 'matriz ou padrão colonial de poder', “o qual ou a qual é um complexo de relações que se esconde detrás da retórica da modernidade (o relato da salvação, progresso e felicidade) que justifica[ria] a violência da colonialidade".

Além dessa situação de conflito -, de usurpação de lotes (para duplicação da estrada de Santarenzinho) e violação de direitos (sem consulta prévia, livre e informada) a comunidade de Santarenzinho vive a angústia e a insegurança de perderem sua autonomia de acesso ao rio Tapajós e à estrada, já que estão sendo cercados por diversos portos. Portos esses pertencentes aos seguintes grupos econômicos: LDC, Cianport, Transportes Bertolini, Odebrecht, Porto Ipiranga, DSR, Porto Tapajós, Unirios.

\begin{abstract}
né então assim ... nós temos acesso pelo rio ... mas por exemplo pra nós vir de lá na na da casa da minha vizinha ... eu aí eu vou ter que fazer o que? ou eu venho por água ou então eu vou ter que arrudiar lá, dois quilômetros de distância pra poder vir bem aqui ... também eu tenho dois dois daqui aqui ali ô ... tem QUATRO dono de terra ... pra você ver daqui até lá em casa não dá um quilometro tem quatro terrenos ... são pequeno né? então esses quatro donos agora eles vão fechar ... eles vão fechar né então meu acesso lá ... ou eu vou ter que fazer um estradinha lá pro fundo pra mim sair lá ou então só pelo rio ... então ... fica essa pergunta ... como ((risos)) a comunidade reage diante disso? (José Maria, Morador de Santarenzinho, entrevista gravada em setembro de 2017).
\end{abstract}

Esse cercamento (fechamento, estrangulamento e obstrução) (Vide Figura 3 que ilustra isso) é forma de obrigar a mercadificação e a privatização da terra e a expulsão de populações tradicionais, isto é, a conversão de várias formas de direitos ("Bem Viver") de propriedade comum e/ou coletiva em direitos exclusivos de propriedade privada corporativa -, com a supressão dos direitos a territórios comuns partilhados e formas autóctones de produção, consumo, relações simbólicas e identitárias. Ou, como assinala Escobar (2019), uma forma de buscar a construção de novos territórios existenciais pautados na lógica capitalista colonial. 
RODRIGUES, J. C

Conflitos territoriais na Amazônia oriental, oeste do estado do Pará: duas situações distintas, mas a mesma lógica imperativa

Figura 3: mapa de localização da Comunidade de Santarezinho e o "cercamento" por portos

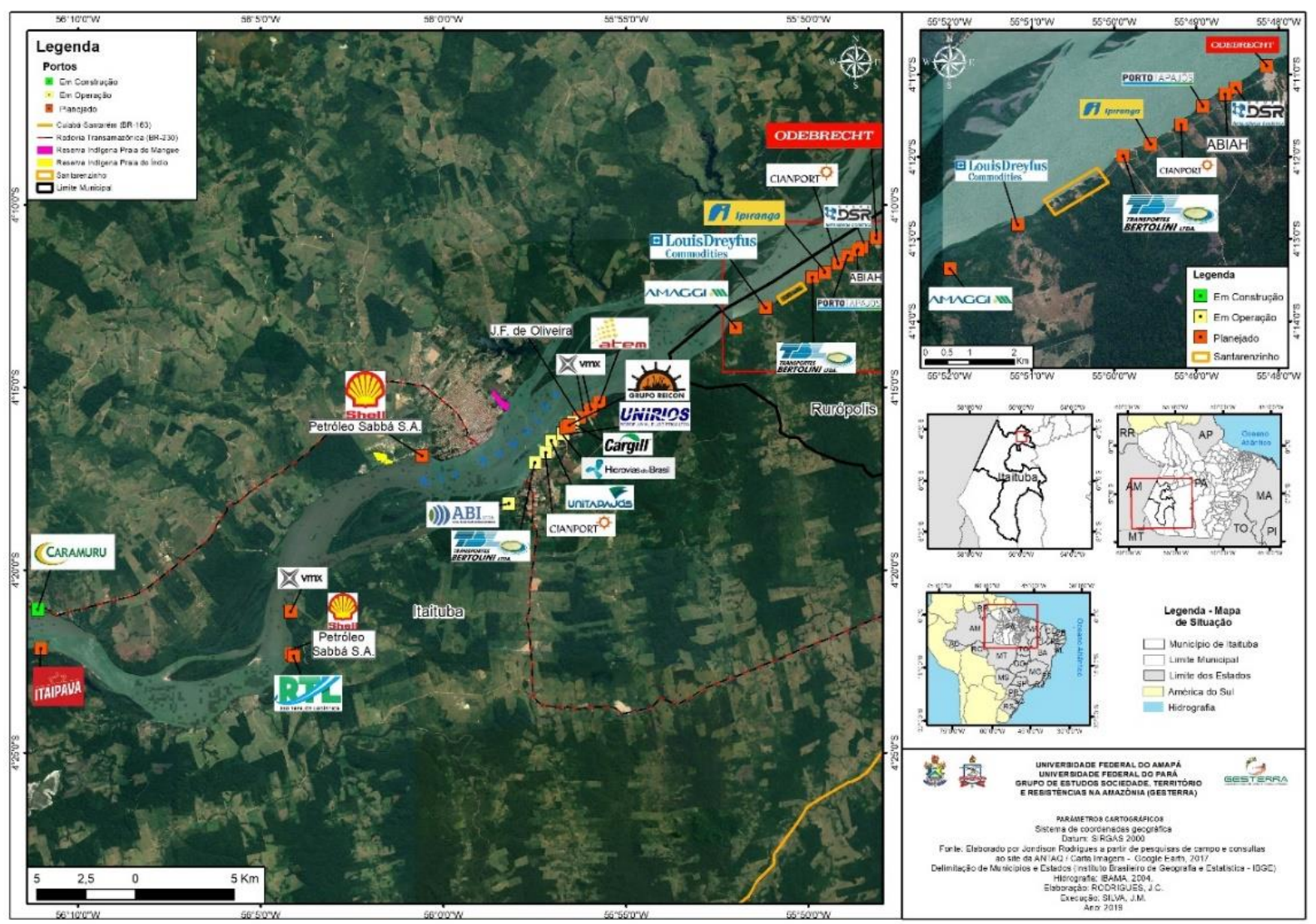

O Oeste do estado do Pará e ao longo do rio e das margens do Tapajós, os diversos territórios passam por um processo de incorporação a desenhos de programas e projetos (já predefinido, sem debate e participação social), com a re-funcionalização dos territórios a serviço de grupos capitalistas, fluxos globais de exploração e espoliação (ESCOBAR, 2019), que possuem forte participação do Estado brasileiro (RODRIGUES, 2018). Como indaga José Maria, morador de Santarenzinho e então presidente da comunidade de Santarenzinho (entrevista gravada em setembro de 2017): “[...] é outro problema que vai ficar na comunidade é ... sério né porque ... que que nós ... moradores daqui podemos fazer diante de uma empresa? É uma pergunta que eu faria a você ... o que que NÓS poderíamos fazer diante de tem dinheiro acima da ... da justiça? acima da lei? Que que nós podíamos fazer?".

Apesar da fala do morador de Santarenzinho, acerca da dificuldade de organizar e enfrentar tal evento conflituoso, as lutas baseadas no lugar, isto é, em defesa da vida, diversidades e de suas territorialidades (ALMEIDA, 2012; ESCOBAR, 2019) conformaram- 
RODRIGUES, J. C.

Conflitos territoriais na Amazônia oriental, oeste do estado do Pará: duas situações distintas, mas a mesma lógica imperativa

se em uma vitória coletiva da comunidade, no que tange a uma nova "área” onde será construída a nova escola, o centro comunitário e o campo de futebol (Figura 4).

Figura 4: Área onde será construída nova escola, centro comunitário e campo de futebol, comunidade de Santarenzinho, Rurópolis, Oeste do Pará

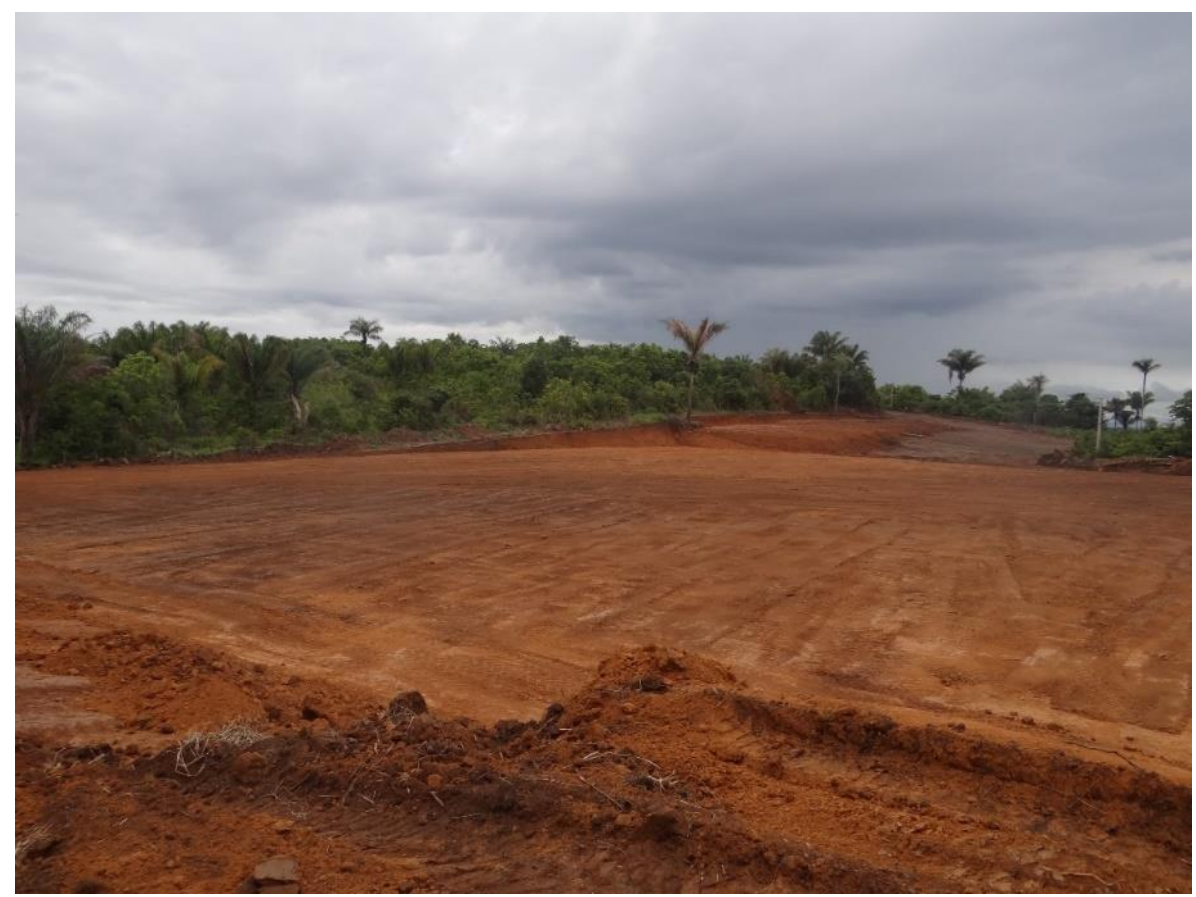

Fonte: registrado por Jondison Rodrigues no dia 08 de dezembro de 2019

Tal resistência configuraria uma espécie de coesão social (territorial), com o rompimento com a tutela e ação mediadora técnico-burocrática do Estado. Aliás, tal ação técnico-burocrática acaba por invisibilizar e diluir a participação e a representatividade das mobilizações políticas em mesas de negociação (ALMEIDA, 2012; BRONZ; ZHOURI; CASTRO, 2020). Mas cabe ainda destacar que seria uma forma de se afirmar e se posicionar em sua zona ontológico-existencial (FANON, 2009), enquanto uma zona humana, de diversidades, solidariedades e de vidas, que aliás, possuem direitos calcados em declarações, constituições e leis.

A coesão social (territorial) também significaria uma defesa do território, da cultura e da identidade da comunidade (ESCOBAR, 2019). Uma forma de demarcação, de posição política contra-hegemônica face à territorialização do agronegócio, pelos seguintes projetos já desenhados: ferroviário (Ferrogrão), hidrelétricos (Complexo São Luiz do 
RODRIGUES, J. C

Conflitos territoriais na Amazônia oriental, oeste do estado do Pará: duas situações distintas, mas a mesma lógica imperativa

Tapajós), Pequenas centrais Hidrelétricas (PHCs, em Rurópolis e Itaituba), portos (mais de quarenta), pátios e postos de combustível.

\section{CONSIDERAÇÕES FINAIS}

O cenário dessa última década no Brasil, em termos de políticas territoriais, pensado e coordenado pelo Estado (em parceria público-privado), foi de ajustes espaciais e macropolíticas, calcados em uma visão progressista-desenvolvimentista e neoextrativista. Cenário esse que vem sendo desenhado, ou, aliás, desenha-se, na escala nacional, principalmente na escala regional, no caso na Amazônia, pela reedição de estratégias políticas seletivas (de espaços e agentes ganhadores) e do capitalismo colonial parasitário.

Tal quadro e racionalidades (arquiteturas de poderes), que vêm se instalando, com lógicas corporativas em escala global, nacional, regional e local, baseados: na exploração de trabalhadores(as), desmatamento, poluição, privatização de espaços de uso coletivo (rio, estradas e rodovias), espoliação de territórios e violação de direitos humanos, étnicos, territoriais e da natureza. Tudo isso muito bem visualizado na Amazônia oriental, mais particularmente, no oeste do estado do Pará, e, tendo como grande protagonista o agronegócio.

Entre os efeitos das ações e políticas do agronegócio, estão os espraiamentos nos territórios - uma configuração de lutas e disputas territoriais, isto é, de conflitos territoriais. Conflitos, por exemplo, que discorremos ao longo artigo, na comunidade de Santenrezinho, com pescadores(as) artesanais. Portanto, conflitos entre populações tradicionais e trabalhadores(as), multinacionais e tradings ligadas ao setor agronegócio (Cargill, Hidrovias do Brasil, Cianport, LDC, ADM, Bertolini, Odebrecht, RTL, VMX, Caramuru, JF Oliveira, Porto Ipiranga, DSR, Porto Tapajós, ATEM, Unirios, Mobile, Cantagalo e Júlio Simões). Ainda com parceria com bancos (o BNDES) e fundos (Pátria investimentos, proprietárias da Hidrovias do Brasil). Cabe destacar que todos esses setores e agentes do agronegócio vêm compor o mosaico de grupos sociais (e disputas) que já compunham a região oeste do estado do Pará: indígenas, ribeirinhos, agroextrativistas, garimpeiros, beiradeiros, palmiteiros, migrantes, fazendeiros, elites locais e populações em geral.

Face a esse mosaico de agentes e diversos usos do território, é que as dinâmicas territoriais também se pluralizam em termos de singularidades de conflitos territoriais, mas 
RODRIGUES, J. C

Conflitos territoriais na Amazônia oriental, oeste do estado do Pará: duas situações distintas, mas a mesma lógica imperativa

possuindo a mesma lógica imperativa de espoliação, advinda da territorialização do agronegócio. Singularidades (especificidades) no que tange "aos territórios em disputa" e às "visões de território", por exemplo, na comunidade Santarezinho e junto a pescadores(as) artesanais. Nessa comunidade o território em disputa foi e é o território físico plural, a "terra" (enquanto território!); já para os(as) pescadores(as) a disputa é pelo rio Tapajós. A “visão de território" é um pouco distinta: a comunidade de Santarezinho vê o território como aquilo que une enquanto comunidade (coesão social), expressão da memória coletiva e da identidade, isto é, de manutenção de práticas, costumes, crenças, tradições e identidades, do qual o território constitui-se lugar de vida. Já para os(as) pescadores(as) artesanais, as "visões de território" perfaz-se por uma espécie de reprodução social e existencial e o território enquanto natureza mãe, que concede alimento, bem estar e existência social.

Tal síntese (nesse artigo) não é apenas a apresentação de conflitos, territórios em disputas, "visões de territórios" de agentes que estão em tais disputais e conflitos, como também não é somente para dar visibilidade a lutas territoriais, aos atores vulneráveis e à profunda naturalização de conflitos e violências. É também para compreender que esses conflitos territoriais não são locais, mas sim globais, já que estão inseridos como mecanismo ou processo de controle monopolístico do território, pois "você espolia as pessoas da sua vizinhança; você espolia as pessoas dos seus espaços de moradia porque quer aqueles espaços para a incorporação" (HARVEY, 2012, p. 17-8). Assim, estão inseridos dentro de políticas e lógicas econômicas interescalares globais que se conectam regiões e territórios, e, manifestam-se em agendas políticas e econômicas que promovem violações que compõe uma “economia de espoliação" (HARVEY, 2012, p. 17).

"Economia de espoliação" que a comunidade de Santarenzinho e os(as) pescadores(as) artesanais estão inclusos, e que podem se intensificar com desembarques de investimentos e políticas estatais autoritárias, de multinacionais, de bancos e de fundos, na Amazônia oriental. Cabe destacar que essa "economia de espoliação" se manifesta ano após ano (particularmente, 2018, 2019 e 2020), por exemplo, com o aumento de taxas de incêndios e desmatamentos, conflitos fundiários, grilagem de terras, ameaças de morte, assassinatos, expulsões de trabalhadores(as) de terras e territórios, trabalho escravo, especulação imobiliária e fundiária. Além disso, conformados pela materialização de uma atmosfera de intimidação e desqualificação por agentes fundiários (fazendeiros, jagunços, pistoleiros e 
RODRIGUES, J. C.

Conflitos territoriais na Amazônia oriental, oeste do estado do Pará: duas situações distintas, mas a mesma lógica imperativa

elites locais). Conflitos intensificados no oeste do estado Pará, desde a eleição para presidente do Brasil, em 2018, de Jair Bolsonaro. Portanto, antecedendo ao destacado por Bronz, Zhouri e Castro (2020, p. 21): “Ainda em janeiro de 2019, nos primeiros dias de governo, foram registradas denúncias de invasão em terras indígenas em todo o Brasil”.

A eleição e consequentemente as ações políticas estatais pautados no discurso autoritário, autorizatório e legitimatório, de práticas violentas, espoliativas sobre a natureza, populações e comunidades, principalmente populações tradicionais, indígenas e agroextrativistas, são visualizadas claramente no Oeste do estado Pará. Práticas violentas e espoliativas que estão inseridas em uma agenda (e ações) anti-cultural, anti-democrática, antiambiental, anti-indígena ${ }^{13}$ e antipopulações tradicionais (além de anti-afrodescendetes e antiLGBTQI+) - uma verdadeira cruzada em termos de eco-cosmo-epistemistecídio - inclusive no período mais intenso de casos e óbitos da pandemia da Covid-19 no Brasil.

O oeste do estado do Pará vive um clima de tensão e ameaças a territorialidades e territórios, que já estava intenso, devido projetos infraestruturais e logísticos: portuários, hidrelétricos, hidroviário, rodoviário e ferroviário, ligados ao agronegócio. Primeiro devido o Projeto de Lei 191/2020, enviado pelo poder executivo (governo Bolsonaro) que vem estabelecer as condições específicas para a realização da pesquisa e da lavra de recursos minerais e hidrocarbonetos e para o aproveitamento de recursos hídricos para geração de energia elétrica em terras indígenas, instituindo a indenização pela restrição do usufruto de terras indígenas. Tal ato Projeto de Lei que desencadeou à interdição do entroncamento entre rodovia Br-163 e Br-230 (no Distrito de Campo Verde, em Itaituba), no dia 02 de setembro de 2020, por cerca de 150 indígenas e garimpeiros. A pauta que sustentou a interdição foi a legalização das atividades de garimpo e liberação da exploração minerária e garimpeira em terras indígenas, no caso, a agilidade da aprovação do Projeto de Lei 191/2020.

Outro clima de tensão e ameaças a territorialidades e territórios é que dia 25 de novembro de 2020, o Governador do estado do Pará, Helder Barbalho, assina o decreto $\mathrm{n}^{\circ}$ $1.190 / 2020$ que regulamenta a Lei Estadual $\mathrm{n}^{\circ}$ 8.878, de 8 de julho de 2019, sobre a

\footnotetext{
${ }^{13}$ No caso, eco-cosmo-epistemistecídio das populações indígenas com a negação (o veto), em julho de 2020 , devido à escassez de acesso às aldeias à água potável, materiais de higiene, leitos hospitalares e respiradores mecânicos, de acordo com a lei (Lei 14.021, de 2020 que prevê medidas e o Plano Emergencial para Enfrentamento de proteção para comunidades indígenas durante a pandemia da Covid-19). Outro eco-cosmoepistemistecídio das populações indígenas se faz por acusações (e ataques) do presidente Jair Bolsonaro às populações indígenas, culpabilizando-os por incêndios generalizados na floresta Amazônica. Acusação realizada na $75^{\mathrm{a}}$ Assembleia Geral da Organização das Nações Unidas (no dia 22 de setembro de 2020).
}

Revista Cerrados, Montes Claros/MG, v. 18, n. 02, p. 474-511, jul./dez.-2020. 
RODRIGUES, J. C.

Conflitos territoriais na Amazônia oriental, oeste do estado do Pará: duas situações distintas, mas a mesma lógica imperativa

regularização fundiária das áreas rurais, e dá outras providências. No Art. $1^{\circ}$ deste Decreto enfatiza sobre a regularização fundiária das áreas rurais sob o domínio do Estado do Pará e/ou áreas rurais sob o domínio da União e dos Municípios, desde que sejam objeto de convênio ou outro instrumento legal apropriado firmado entre os respectivos entes competentes. Dispositivo jurídico esse que acaba por fortalecer grilagens de terras, especulação fundiária, produção de um mercado de terras e aquisição de terras por estrangeiros. Em síntese uma corrida por compra de terras, principalmente no oeste do estado do Pará, fonte de vários projetos privados de investimentos. Tais resultados ou efeitos que constituirão futuramente outros resultados de pesquisa, assim como outros artigos científicos.

\section{AGRADECIMENTOS}

Ao CNPQ e a FEPEAP/CAPES pela bolsa, respectivamente, de Doutorado e Pós-Doutorado, ao autor do artigo. Ao MAB, CPT, IBASE, Terras de Direitos, pelos diálogos e entrevistas. Também agradecemos ao Grupo de Pesquisa sobre Estado, Território, Trabalho e Mercados Globalizados/GETTAM (coordenado pela professora Edna Castro, da Universidade Federal do Pará/UFPA) e o Grupo de Pesquisa sobre Sociedade, Território e Resistência na Amazônia/GESTERRA (Coordenado pelos professores: Solange Gayoso e Marcel Hazeu/UFPA) pelos ensinamentos, diálogos e participações formativas e autoformativa.

\section{REFERÊNCIAS}

ACOSTA, A. O Bem Viver. São Paulo: Autonomía Literaria y Editora Elefante, 2016.

ACSELRAD, H. Ambientalização das lutas sociais - o caso do movimento por justiça ambiental. Estudos Avançados, [S./l.], v. 24, n. 68, p. 103-111, 2010.

ACSELRAD, H. Disputas cognitivas e exercício da capacidade crítica: o caso dos conflitos ambientais no Brasil. Sociologias, [S./l.], v. 16, n. 35, p. 84-105, 2014.

ALMEIDA, A. W.B. Territórios e territorialidades específicas na Amazônia: entre a "proteção" e o "protecionismo". Caderno CRH, [S./l.], v. 25, n. 64, p. 63-71, 2012.

ÁLVAREZ, L.; COOLSAET, B. Decolonizing Environmental Justice Studies: A Latin American Perspective. Capitalism Nature Socialism, [S./l.], v. 31, n. 2, p. 50-69 2020.

ARAUJO, R. S. B.; CASTRO, E. M. R. Desenvolvimento e conflitos na Amazônia: um olhar sobre a colonialidade dos processos em curso na BR-163. Revista NERA, [S./l.], v. 42, p. 51$73,2018$.

BALLESTRIN, L. Modernidade/Colonialidade sem "Imperialidade"? O Elo Perdido do Giro Decolonial. Dados, [S./l.], v. 60, n. 2, p. 505-540, 2017. 
RODRIGUES, J. C.

Conflitos territoriais na Amazônia oriental, oeste do estado do Pará: duas situações distintas, mas a mesma lógica imperativa

BENATTI, J. H. et al. Questão fundiária e sucessão da terra na fronteira Oeste da Amazônia. Revista Novos Cadernos NAEA, [S./l.], v. 11, p. 85-122, 2008.

BERTAUX, D. O "relato de vida" como método das ciências sociais: Entrevista com Daniel Bertaux. Tempo Social, [S./l.], v. 32, n. 1, p. 319-346, 2020.

BOURDIEU, P. Habitus, code et codification. Actes de la recherche en sciences sociales, v. 64, p. 40-44, 1986.

BOURDIEU, P. Razones práticas - sobre la teoria de la acción. Barcelona: Anagrama, 1997. BOURDIEU, P. Doxa y vida cotidiana. In: ZIZEK, S. (Ed). Ideología - Um mapa de la cuestión. Buenos Aires: FCE, 2003. p. 295-308.

BOURDIEU, P. Sobre o Estado. São Paulo: Companhia das Letras, 2014.

BRASIL. Decreto no 6.040, de 7 de fevereiro de 2007. Institui a Política Nacional de Desenvolvimento Sustentável dos Povos e Comunidades Tradicionais. Brasília, 2007.

BRONZ, D.; ZHOURI, A.; CASTRO, E. Passando a boiada: violação de direitos, desregulação e desmanche ambiental no Brasil. Revista Antropolítica, [S./l.], n. 49, p.8-41, 2020 .

CASTRO, E. M. R. Sociedade, Território e Conflitos: a Br 163 em Questão. Belém: NAEA/UFPA, 2008.

CASTRO, E. M. R.; CAMPOS, I. Formação Socioeconômica do Estado do Pará. In: CASTRO, E. M. R.; CAMPOS, I. (Orgs.). Formação Socioeconômica da Amazônia. Belém: NAEA, 2015.

CASTRO, E. M. R. Amazônia na encruzilhada entre o saque colonial e as lutas de resistência. In: CASTRO, E. M. R. (Org.). Territórios em transformação na Amazônia. Belém: UFPA/NAEA, 2017a. p. 19-48.

CASTRO, E. M. R. Introdução a territórios em transformação. In: CASTRO, E. M. R. (Org.). Territórios em transformação na Amazônia. Belém: UFPA/NAEA, 2017b. p. 7-16.

CASTRO, E. M. R. Neoextractivismo en la mineria, prácticas coloniales y lugares de resistencia en Amazonia, Brasil. Perfiles Económicos, [S./1.], v. 5, p. 35-76, 2018.

CASTRO, E. M. R. Razão decolonial, experiência social e fronteiras epistemológicas. In: CASTRO, E. M. R. (Org.). Pensamento crítico latino-americano. São Paulo: Editora Annablume/Editora CLACSO, 2019. p. 35-62.

CPT - Comissão Pastoral da Terra. Conflitos no Campo: Brasil de 2019. Goiânia: CPT Nacional, 2020. 
RODRIGUES, J. C.

Conflitos territoriais na Amazônia oriental, oeste do estado do Pará: duas situações distintas, mas a mesma lógica imperativa

CRUZ, J. N.; HAZEU, M. T. Água em estado vivo: conflito socioambiental e r-existência em torno do rio Dendê, Barcarena, Pará. Revista de Políticas Públicas, [S./l.], v. 24, n. 1, p. 28 48, 2020.

FANON, P. Piel negra, máscaras blancas. Madrid: Akal, 2009.

FERNÁNDEZ-LLAMAZARES, A. et al. A State-of-the-Art Review of Indigenous Peoples and Environmental Pollution. Integrated Environmental Assessment and Management, [S./l.], v. 16, n. 3, p. 324-341, 2020.

FLEURY, L. C.; ALMEIDA, J.; PREMEBIDA, A. O ambiente como questão sociológica: conflitos ambientais em perspectiva. Sociologias, [S./1.], v. 16, n. 35, p. 34-82, 2014.

FLEURY, L. C.; BARBOSA, R. S.; SANT'ANA JÚNIOR, H. S. Sociologia dos conflitos ambientais. Revista Brasileira de Sociologia, [S./l.], v. 5, n. 11, p. 219-253, 2017.

FONSECA, A. A. M. Localismo, desempenho institucional e (in)justiça territorial.

Cuadernos de Geografía: Revista Colombiana de Geografía, [S./l.], v. 29, n. 2, p. 473492, 2020.

GONCALVES, O. D.; RODRIGUES, J. C.; SOBREIRO FILHO, J. Marés das rebeldias em Abaetetuba: dos rios da existência à resistência dos territórios na Amazônia paraense, Baixo Tocantins. Revista Tamoios, [S./l.], v. 15, n. 1, p. 80-103, 2019.

GÓMEZ-SOTO, W. H.; SILVA, R. H. A expansão dos empreendimentos portuários e seus efeitos sociais na vida cotidiana dos pescadores da Vila Nova - São José do Norte (RS).

Estudos Sociedade e Agricultura, [S./1.], v. 25, n. 1, p. 131-152, 2017.

GUDYNAS, E. Buen vivir: Germinando alternativas al desarrollo Eduardo Gudynas. América Latina em Movimento, [S./1.], n. 462, p. 1-20, 2011.

GUDYNAS, E. Nuevas coyunturas entre extractivismos y desarrollo Los límites del concepto de populismo y la deriva autoritária. Ecuador Debate, [S./l.], n. 105, p. 23-45, 2018.

HARVEY, D. O neoliberalismo: história e implicações. São Paulo: Loyola, 2008.

HARVEY, D. A urbanização e as crises. A urbanização e as crises. Pós, [S./l.], v. 19, n. 32, p. 10- 24, 2012.

HAZEU, M. T. O não-lugar do outro: sistemas migratórios e transformações sociais em Barcarena. 2015. 337f. Tese (Doutorado em Desenvolvimento Socioambiental) Universidade Federal do Pará, Programa de Pós-Graduação em Desenvolvimento Sustentável do Trópico Úmido, Belém, 2015.

KOTHARI, A. et al. Hallar senderos pluriversales. Revista del CESLA, [S./l.], v. 25, p. 3-24, 2020 
RODRIGUES, J. C.

Conflitos territoriais na Amazônia oriental, oeste do estado do Pará: duas situações distintas, mas a mesma lógica imperativa

LASCHEFSKI, K. Licenciamento e Equidade Ambiental: As racionalidades distintas de apropriação do ambiente por grupos subalternos. In: ZHOURI, A. (Org.). As Tensões do Lugar. Belo Horizonte: Editora UFMG, 2011. p. 21-60.

LASCHEFSKI, K.; ZHOURI, A. Povos indígenas, comunidades tradicionais e meio ambiente: a 'questão territorial' e o novo desenvolvimentismo no brasil. Revista Terra Livre, [S./1.], v. 1, n. 52, p. 278-322, 2019.

LEFF, E. Encountering political ecology: epistemology and emancipation. In: BRYANT, R. (Ed.). The International Handbook of Political Ecology. Chelteham: Edward Elgar Publishing, 2015. p. 44-56.

LEFF, E. Reexistencia. In: D’ALISA, D.; DEMARIA, F.; KALLIS, G. Decrecimiento: un vocabulario para una nueva era. 2 ed. Cidade do México: Icaria editorial, s. a./Fundación Heinrich Boell, 2018. p. 357-359.

LOUREIRO, V. R. Amazônia: da dependência a uma nova situação colonial. In: CASTRO, E. (Org.). Pensamento crítico latino-americano. São Paulo: Annablume, 2019. p. 197-224.

MAGALHÃES, S. B. Lamento e Dor: Uma análise sócio-antropológica do deslocamento compulsório provocado pela construção de barragens. 278 f. Tese (Doutorado em Sociologia e Antropologia) - Universidade Federal do Pará, Programa de Pós-Graduação em Ciências Sociais, Belém, 2007.

MARTINEZ-ALIER, J. Conflitos de distribuição ecológica num contexto de incerteza. In: CABRAL, M. V.; GARCIA, J. L.; JERÓNIMO, H. (Orgs.). Razão, Tempo e Tecnologia: Estudos em Homenagem ao Professor Hermínio Martins, Lisboa, Imprensa de Ciências Sociais, 2006. p. 411-487.

MARTINEZ-ALIER J.; M. O'CONNOR. Ecological and economic distribution conflicts. In: COSTANZA, R.; J. MARTINEZ-ALIER, J.; SEGURA, O. (Ed.). Getting down to Earth: Practical Applications of Ecological Economics. Washington: Island Press/ISEE, 1996.

MARTINEZ-ALIER J.; ROY, B. Editorial: Some Insights on the Role of Violence. Ecology, Economy and Society-the INSEE Journal, [S./1.], v. 2, n. 1, p. 27-30, 2019.

MIGNOLO, W. D. Colonialidade: o lado mais escuro da modernidade. Revista Brasileira de Ciências Sociais, [S./1.], v. 32, n. 94, p. 1-18, 2017 a.

MIGNOLO, W. Desafios decoloniais hoje. Epistemologias do Sul, [S./l.], v. 1, n. 1, p. 12-32, 2017b.

MIKATI, M. For a Dialectics of nature and need: unity, separation, and alienation.

Capitalism Nature Socialism, [S./l.], v. 31, n.1, p. 34-51, 2020.

MINAYO, M. C. S. Disciplinaridade, interdisciplinaridade e complexidade. Emancipação (Online), [S./1.], v. 10, n. 2, p. 437-444, 2010. 
RODRIGUES, J. C.

Conflitos territoriais na Amazônia oriental, oeste do estado do Pará: duas situações distintas, mas a mesma lógica imperativa

MINAYO, M. C. S. Análise qualitativa: teoria, passos e fidedignidade. Ciência e Saúde Coletiva, [S./1.], v. 17, n, 3, p. 621-626, 2012.

MONIÉ, F. Análise geopolítica dos conflitos territoriais na área de influência do Complexo Portuário e Industrial do Açu - São João da Barra, RJ. Cadernos do Desenvolvimento Fluminense, [S./1.], v. 09, p. 69-83, 2016.

MOREIRA, R. Em Busca dos fundamentos: o problema da identidade e do método - Parte I: a geografia da totalidade. Revista Ciência Geográfica, [S./l.], v. 24, n. 1, p. 107-113, 2020.

MORETTI, R.; COX, M. Impactos socioambientais ao longo da implantação e consolidação do Complexo Industrial Portuário de Suape - PE. Gaia Scientia (UFPB), [S./l.], v. 10, p. 98$105,2016$.

PAULA, C. Q. A Pesca artesanal na geografia brasileira: impactos/conflitos, ambientes/ territórios. PARA ONDE!? (UFRGS), [S./l.], v. 12, n. 1, p. 01-08, 2019.

PAULA, C. Q. A. Conflitos por território na pesca artesanal brasileira. Revista NERA, [S./1.], v. 23, n. 51, p. 180-204, 2020.

PAULA, C. Q.; SUERTEGARAY, D. M. A. Modernização e pesca artesanal brasileira: a expressão do "mal limpo". Revista Terra Livre, [S./l.], v. 1, n. 50, p. 97-130, 2018.

RADAELLI, A.; VARGAS, F; FLEURY, L. Ciências sociais, ambientes e o debate colonial: uma introdução. Revista Contraponto, [S./l.], v. 6, n. 2, p. 1-8, 2019.

ROCHA, B. C. et al. Na margem e à margem: arqueologia amazônica em territórios tradicionalmente ocupados. Amazônica: Revista de Antropologia (Online), [S./l.], v. 6, n. 2, p. 358-384, 2014.

RODRIGUES, J. C. O Estado a contrapelo: lógica, estratégias e efeitos de complexos portuários no oeste do Pará. 383 f. Tese (Doutorado em Desenvolvimento Socioambiental) Universidade Federal do Pará, Belém, 2018.

RODRIGUES, J. C.; RODRIGUES, J. C. A produção de complexos portuários no município de Itaituba, Oeste do Pará: lógicas e contradições das políticas públicas. Caminhos de Geografia, [S./1.], v. 16, n. 56, p. 1-21, 2015.

RODRIGUES, J. C.; LIMA, R. A. P. Grandes projetos de infraestrutura na Amazônia: imaginário, colonialidade e resistências. Revista NERA, [S./l.], v. 23, p. 89-116, 2020.

SANT'ANA JÚNIOR, H. A.; LOPEZ, J. I. A.; PEDRO, V. V. Cajueiro: Terminal Portuário, Resistência Popular e Conflito Ambiental em São Luís do Maranhão. In: In: CASTRO, E.; CARMO, E. D. (Orgs.). Dossiê Desastres e Crimes da Mineração em Barcarena. Belém: NAEA/UFPA, 2019. p. 53-68. 
RODRIGUES, J. C.

Conflitos territoriais na Amazônia oriental, oeste do estado do Pará: duas situações distintas, mas a mesma lógica imperativa

SHIEDEL, A. et al. Environmental conflicts and defenders: a global overview. Global Environmental Change, [S./l.], v. 63, p. 1-12, 2020.

SILVA, D. M.; ARAÚJO, D. O. A; SILVA, M. F. L. As determinações epistemológicas da Justiça ambiental no âmbito da complexidade dos valores do meio ambiente. Revista Eletrônica Mestrado em Educação Ambiental, [S./l.], v. 36, n. 2, p. 391 - 408, 2019.

SVAMPA, M. Commodities Consensus: Neoextractivism and Enclosure of the Commons in Latin America. The South Atlantic Quarterly, [S./l.], v. 114, n. 1, p. 65-82, 2015.

SVAMPA, M. Yers un néoextractivisme aux formes extrêmes. Recherches internationales, [S./l.], n. 115, p. 145-165, 2019.

TEIXEIRA, R. O. S.; ZHOURI, A; MOTTA, L. D. Os estudos de impacto ambiental e a economia de visibilidades do desenvolvimento. Revista Brasileira de Ciências Sociais, [S./l.], v. 36, n. 105, p. 1-18, 2020.

TORRRES, M. Terra privada, vida devoluta: ordenamento fundiário e destinação de terras públicas no Oeste do Pará. 2012. 879 f. Tese (Doutorado em Geografia) - Universidade de São Paulo, Programa de Pós-Graduação em Geografia, São Paulo, 2012.

VIEIRA, T. W. M. Novo desenvolvimentismo e conflitos ambientais: o Complexo Petroquímico do Estado do Rio de Janeiro e os pescadores artesanais da Baía de Guanabara. 2015. 126 f. Dissertação (Mestrado em Ciências Ambientais e Conservação) - Universidade Federal do Rio de Janeiro, Programa de Pós Graduação em Ciências Ambientais e Conservação, Rio de Janeiro, 2015.

VIEIRA, T. W. M.; LEAL, G. F.; LEMES, R. M. Novo desenvolvimentismo e conflitos ambientais na Baía de Guanabara. Desenvolvimento e Meio Ambiente, [S./1.], v. 42, p. 271286, 2017.

ZACARDI, D. M.; PONTE, S. C. S.; SILVA, A. J. S. Caracterização da pesca e perfil dos pescadores artesanais de uma comunidade às margens do Rio Tapajós, Estado do Pará. Amazônia: Ciência \& Desenvolvimento, [S./l.], v. 10, n. 19, p. 129-148, 2014.

ZHOURI, A. From 'participation' to 'negotiation': supressing dissent in environmental conflict resolution in Brazil. In: BRYANT, R. (Ed.). The International Handbook of Political Ecology. Chelteham: Edward Elgar Publishing, 2015. p. 447-459.

ZHOURI, A. Megaprojects, epistemological violence and environmental conflicts in Brazil. Perfiles Económicos, [S./1.], n. 5, p. 7-33, 2018. 
Conflitos territoriais na Amazônia oriental, oeste do estado do Pará: duas situações distintas, mas a mesma lógica imperativa

\section{Autor}

Jondison Cardoso Rodrigues - É Graduado em Ciências Ambientais, Mestre em Ciências Ambientais e Doutor em Desenvolvimento Socioambiental pela Universidade Federal do Pará (UFPA). Atualmente é pesquisador e membro dos Grupos de Pesquisa da Universidade Federal do Pará (UFPA).

Artigo recebido em: 23 de agosto de 2020. Artigo aceito em: 30 de novembro 2020. Artigo publicado em: 07 de dezembro 2020. 